\title{
Vascular flora associated to Mediterranean temporary ponds on the island of Minorca
}

\author{
by \\ Pere Fraga i Arguimbau \\ Projecte LIFE BASSES, Departament d'Economia i Medi Ambient, Consell Insular de Menorca, \\ E-07703 Maó, Menorca, Illes Balears, Spain \\ pfa.life@cime.es
}

\begin{abstract}
Fraga i Arguimbau, P. 2008. Vascular flora associated to Mediterranean temporary ponds on the island of Minorca. Anales Jard. Bot. Madrid 65(2): 393-414.

Mediterranean temporary ponds are a habitat with a high interest for conservation due to their particular characteristics and especially to their biodiversity. Vascular flora is a feature that stands out for its richness and diversity. Minorca has a high representation of this habitat. A complete inventory of vascular plants related to this habitat on the island is presented here for the first time. 360 taxa have been recorded in the pond areas. Most of them are usually found outside the water influence, and just 35 have been found to be exclusive to the inundation area. The quantitative analysis of additional information like abundance within the island, chorology and life forms, compared with that of all the flora on the island, reveals some particular traits for the flora of this habitat, and especially for the plants of the inundated area.
\end{abstract}

Keywords: Mediterranean temporary ponds, vascular plants, chorology, life forms, Minorca Island, Spain.

\section{Introduction}

Mediterranean temporary ponds are a habitat that stand out for their biodiversity, both in a quantitative and in a qualitative sense. This main feature is a result of its particular water dynamic that relies mainly on rainfall (Zedler, 1987; Keeley \& Zedler, 1998). The alternation of wet and dry phases, often irregular, creates an environment with extreme living conditions that favour the presence of a unique biodiversity exclusive or mostly restricted to this habitat (Holland \& Jain, 1981a, b; Zedler, 1987; Holland \& Jain, 1988, 1990; Keeley \& Zedler, 1998; Grillas, 2004). Especially the vascular flora shows a richness of species that

\section{Resumen}

Fraga i Arguimbau, P. 2008. Flora Vascular asociada a los humedales temporales mediterráneos en la isla de Menorca. Anales Jard. Bot. Madrid 65(2): 393-414 (en inglés).

Los humedales temporales mediterráneos están catalogados como hábitats prioritarios de conservación en la Unión Europea por sus características ambientales y por su elevada biodiversidad, en la que destaca su interesante flora vascular. En la isla de Menorca se encuentra una notable representación de este tipo de ecosistema acuático. En este trabajo se ofrece, por primera vez, un inventario completo de la flora asociada a estos ambientes. Se han identificado 360 táxones, de los cuales solamente 35 están relacionados con las zonas inundadas. El análisis realizado para cada taxon -abundancia en la isla, corología y biotipos-, comparado con el realizado para el conjunto de la flora de la isla, pone de manifiesto algunos aspectos peculiares de la mencionada flora de estos hábitats, especialmente para los táxones exclusivos de la zona inundada.

Palabras clave: humedales temporales mediterráneos, flora vascular, corología, distribución, isla de Menorca, España.

make these seasonal ponds like small singular islands in its surrounding vegetation (Stone, 1990; Baskin, 1994). Moreover, this habitat also shows a diversity of types according to factors like geology or landform (Jones \& Stokes, 1990; Smith \& Verrill, 1998; Yavercovsky \& al., 2004), another factor that contributes to its high biodiversity. All these particular characteristics together with their typically reduced dimension and strong dependence on rain water makes them highly sensitive to alterations, even those of apparent low intensity (Barry, 1996; Rhazi \& al., 2001; Gauthier \& al., 2004). Due to all these characteristics this habitat is included in the Habitats Directive of the European Union. 
Particular features like geological diversity, the presence of impermeable soils, and rainy winters provide Minorca with an important representation of this habitat, not only in number, but also in diversity (Fraga \& al., 2007), and up to six main types can be distinguished (Figs. 1-3). An elevated number of seasonal ponds have been related to human activity since ancient times. Some of the most important are close to archaeological sites from the megalithic culture and until not so many years ago they were still used and appreciated as a natural fresh water source for cattle. Despite this importance little was known about the state of conservation and real distribution of this habitat on the island. Only an unpublished paper on wetlands (Pretus, 1990) included some information. Aware of this situation in 2004, the Consell Insular de Menorca promoted a proposal for a LIFE Nature project ("Management and conservation of Mediterranean temporary ponds in Minorca" - LIFE05/ NAT/ES/000058 LIFE BASSES) with one primary objective: the long-term conservation of this habitat on the whole island. Improving awareness of the associated vascular flora is an essential step in the implementation of management plans for this habitat.

\section{Material and methods}

As many as 63 temporary ponds are catalogued in the project (Fig. 4). For each of these ponds, at least the completion of two inventories of vascular flora has been accomplished, one in the inundation phase and another in the dry phase. But for the majority, additional inventories and annotations were occasionally carried out during the periodical visits made for other activities of the project. The plant checklist of each pond was introduced into a database which contains other information related to the flora of Minorca like the abundance within the island, biogeography, life forms, or legal protection. All these data sets were compiled before for the elaboration of the checklist of vascular flora on the island (Fraga \& al., 2004), so any further analysis of the collected data could be relevant to the flora as a whole.

Several studies have shown that species distribution within a pond is related to the duration of inundation and water influence (Zedler, 1987; Holland \& Jain, 1988; Crowe \& al., 1994; Bauder, 2000; Barbour \& al., 2003; Barbour \& al., 2005). At the same time, there seems to be reciprocal influence between the vegetation of the pond and that of the surrounding area (Rhazi \& al., 2001). Taking these facts into account, the inventory of the vascular flora was not limited to the inundation area. The immediate bordering area and a strip of vegetation around each pond were also surveyed with hopes of obtaining additional in- formation about the environment in which the pond is located. In this way the plant taxa recorded could be classified into four groups according to their distribution and annual life cycle: plants that usually grow in the inundation area during the aquatic phase (IFA), plants that usually grow in the inundation area during the dry phase (IFS), plants that usually grow in the border zone (MG), which is the strip of land adjacent to the inundation area but rarely becomes inundated, and plants that usually grow in the terrestrial vegetation surrounding the pond (OR).

In order to perform a comparison with the flora from the rest of the island, the nomenclature, the abundance, life forms and chorological type for each taxa follows those established by Fraga \& al. (2004). Collected specimens are stored in the Herbarium Generale Minoricae.

\section{Results and discussion}

The general results of the inventories of vascular plants in 63 Mediterranean temporary ponds of Minorca show that at least 360 taxa of vascular plants are related to this habitat (see appendix), this makes up $27 \%$ of all that on the island. Most of them $(69 \%)$ grow outside the inundation areas (MG and OR), and among plants growing in the inundation area (IFS and IFA), just 35 taxa are area exclusive (Fig. 5). The table in the appendix shows the list of recorded taxa with additional information (abundance, chorological type, life form) and their habitual presence in the zones defined above.

A simple quantitative analysis of this information, especially when compared to that from the catalogue of vascular flora (Fraga \& al., 2004), helps to learn more about the scientific and ecological importance of this habitat and its state of conservation.

\section{Abundance}

The results for abundance (Table 1) show that plants widely distributed within the island (common and very common) are the most significant group $(75 \%)$. This is quite different from the flora of the whole island where they make up only $45 \%$. These results could be either a confirmation of good representation of this habitat in Minorca, or that it is simply located in areas with plant communities widespread throughout the island.

An analysis of the abundance only for the plants growing in the inundation area may help to solve this question. Although these results (Table 1) still show the most common plants as the most represented, all the values are more equilibrated. Thus it can be said that most of the vegetation surrounding temporary 


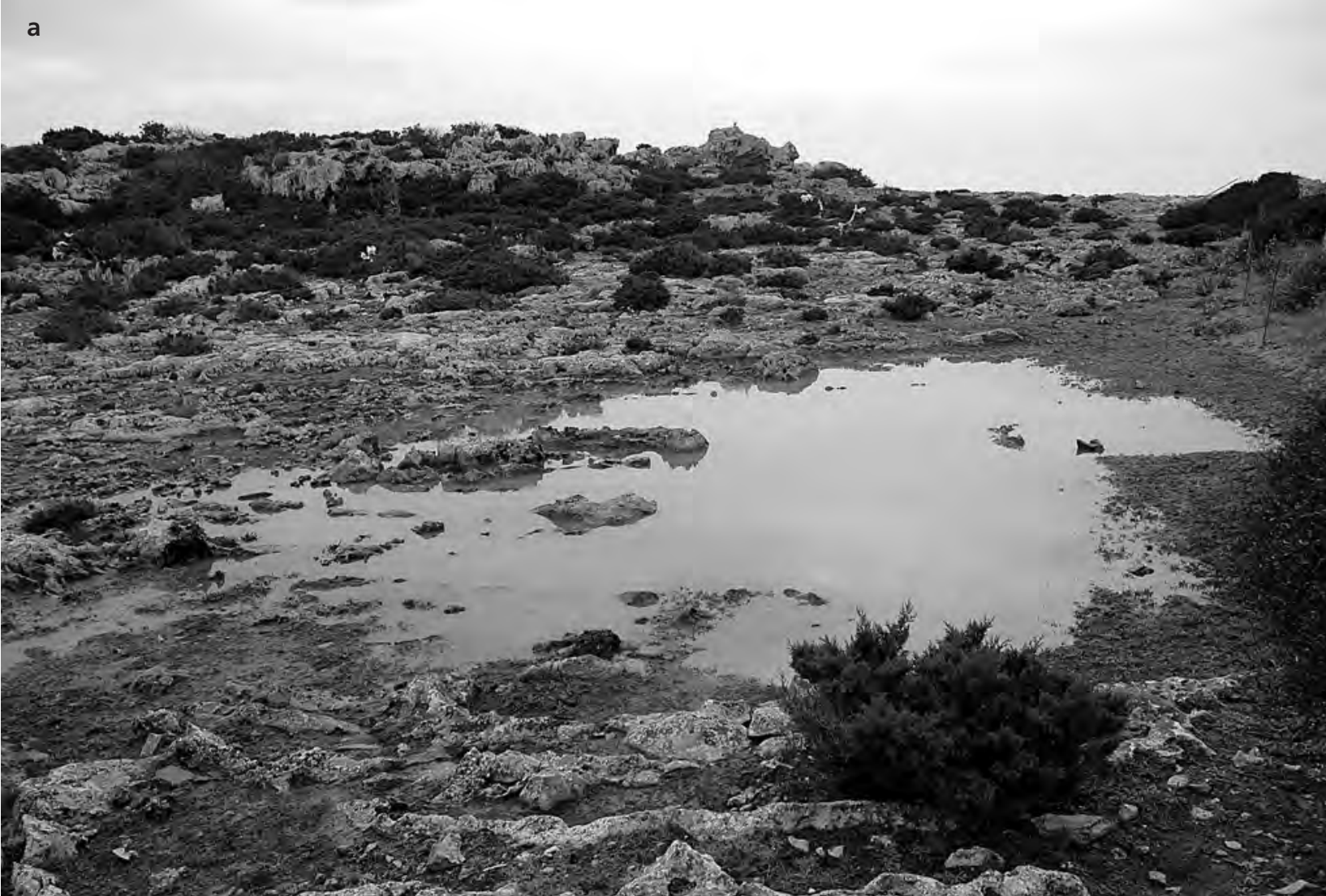

b

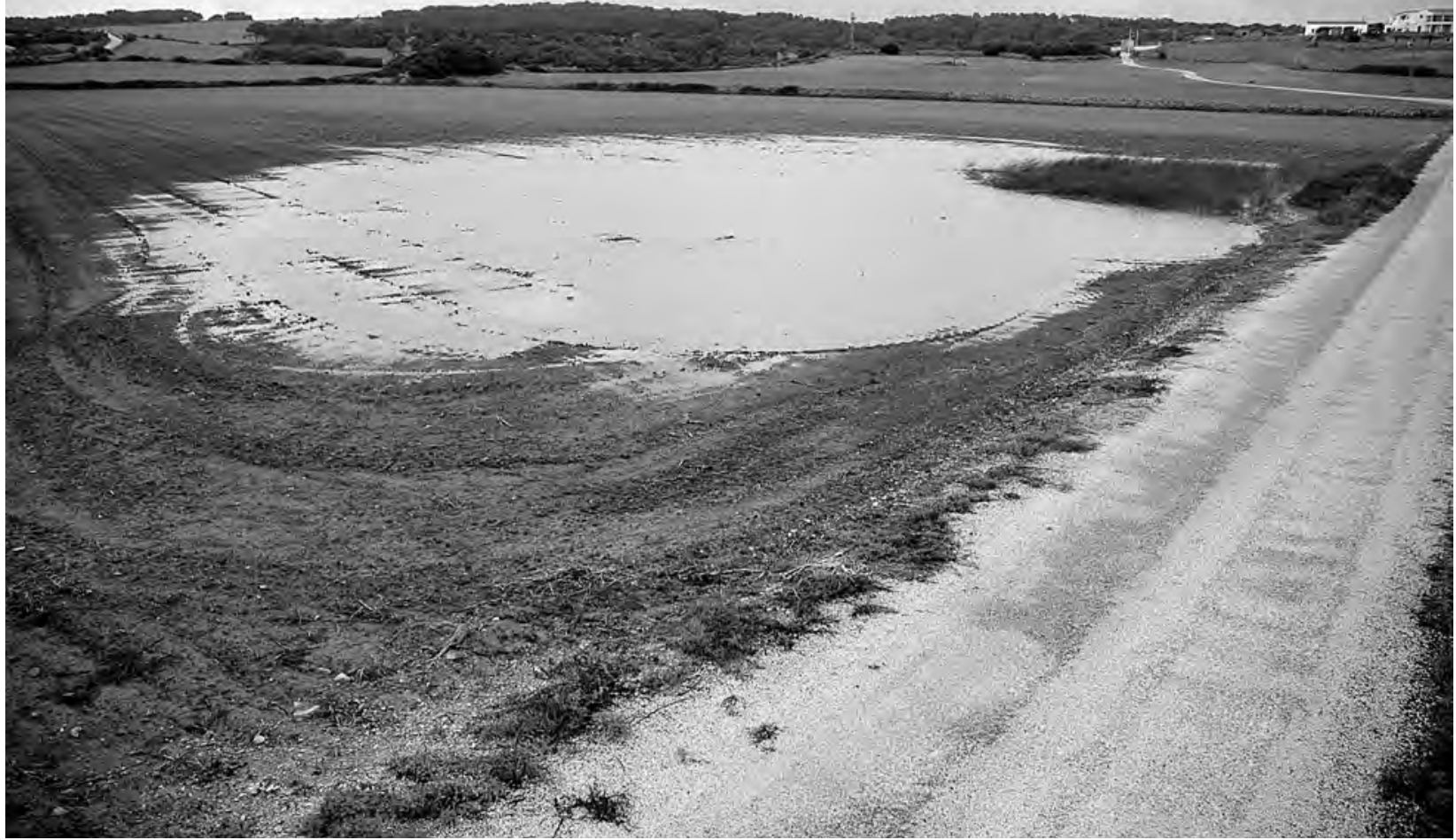

Fig. 1. a, Coastal temporary pond on rocky outcrops. b, Inland temporary pond on deep sandy soils. 

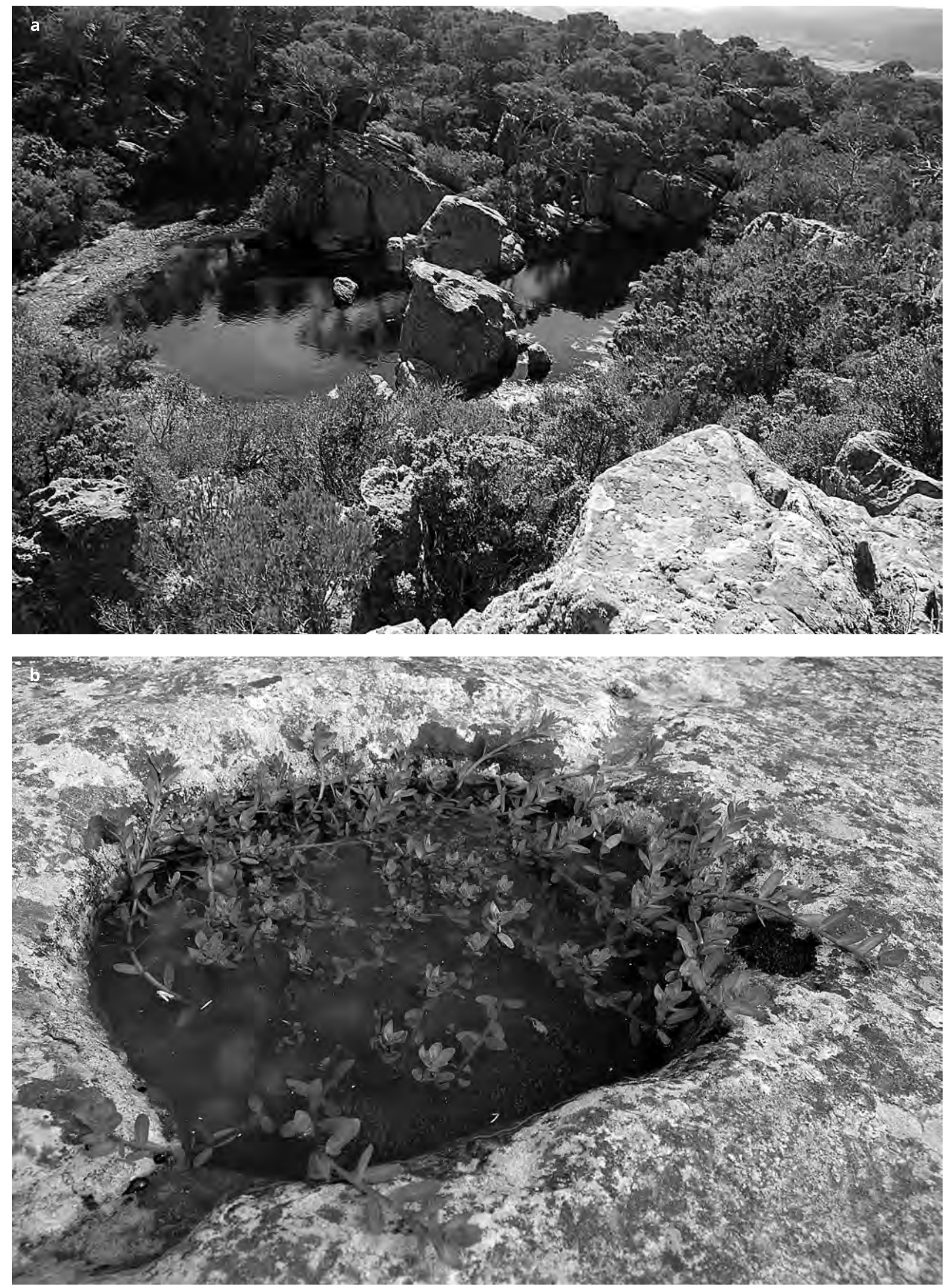

Fig. 2. a, Temporary ponds on siliceous sandstone derived soils. b, Rockpool. 

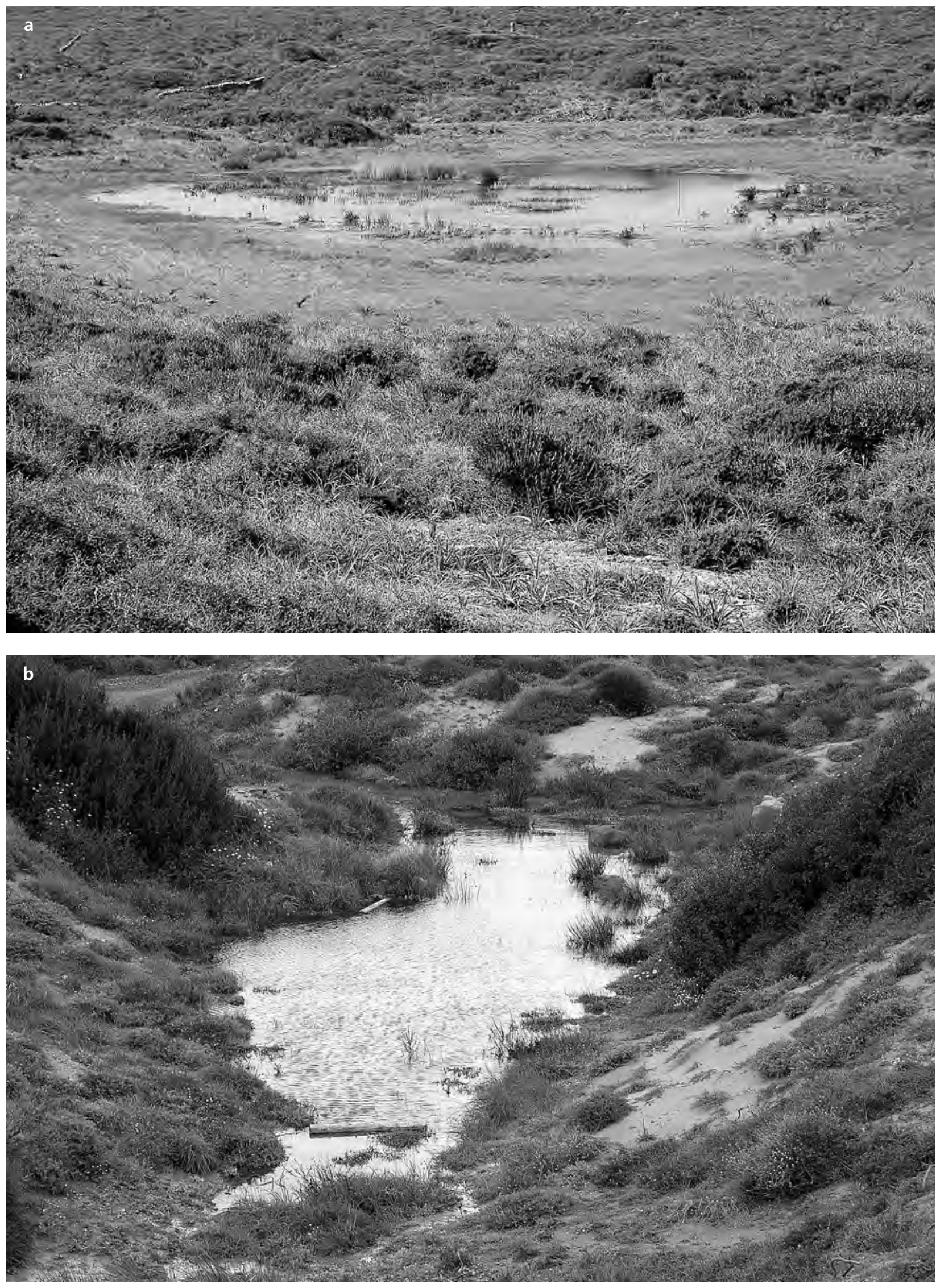

Fig. 3. a, Temporary pond in shallow depresions on palaeozoic soils. b, Ephemeral temporary ponds on sandy coastal soils. 


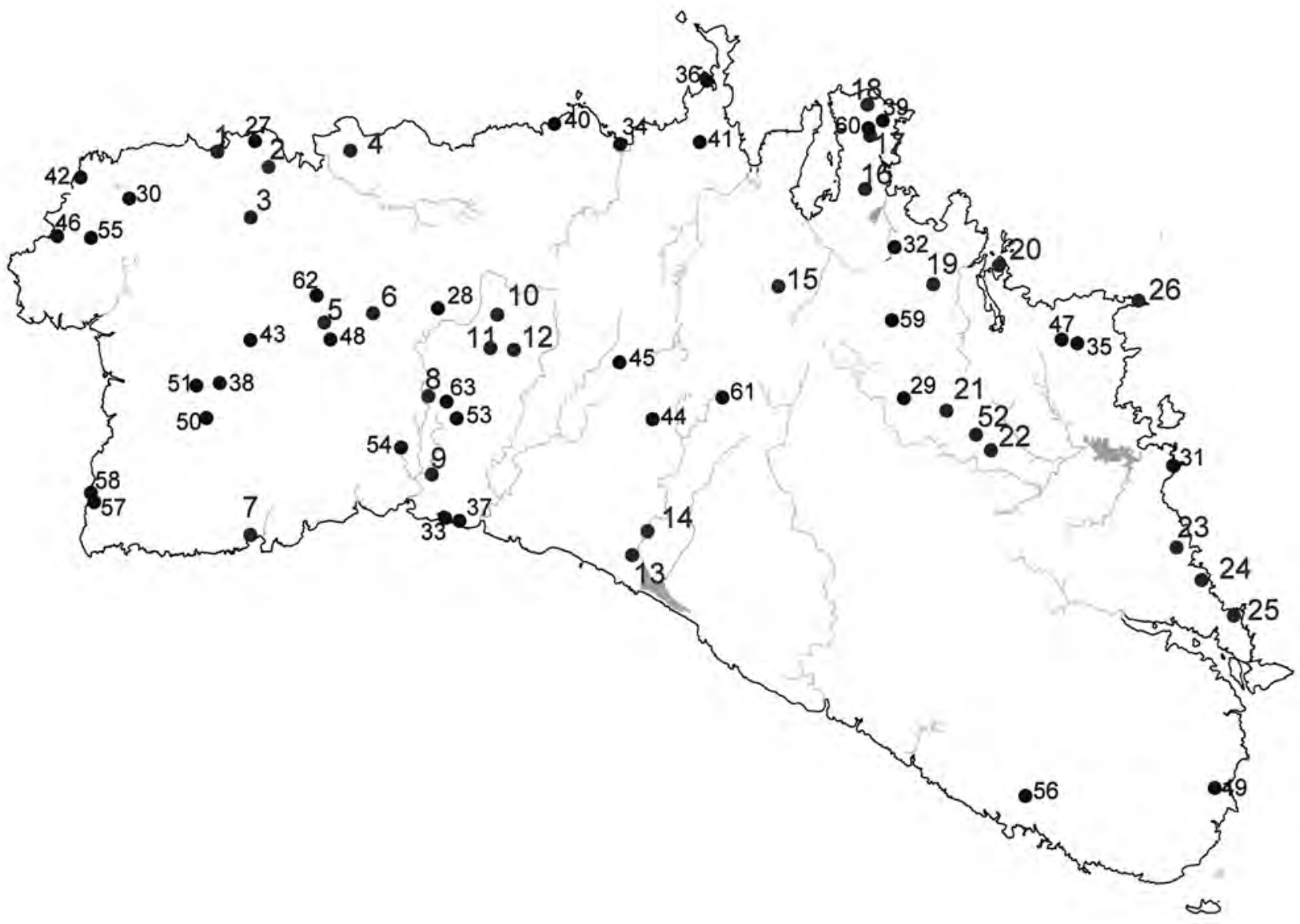

Fig. 4. Distribution of temporary ponds of Minorca Island studied in this work.

Table 1. Representation (\%) of the abundance categories within the inundation area, the whole pond area and the vascular flora of Minorca (Fraga \& al., 2004).

\begin{tabular}{|l|c|c|c|}
\hline Abundance & Inundation area & Whole pond area & Flora of Minorca \\
\hline Very common & 18,7 & 34,0 & 29,4 \\
\hline Common & 36,4 & 41,0 & 23,3 \\
\hline Rare & 23,4 & 15,0 & 30,3 \\
\hline Very rare & 21,5 & 10,0 & \\
\hline
\end{tabular}

ponds in Minorca is mainly formed by plant species with a wide distribution within the island, but in the areas of inundation the species are quite less widespread or even quite rare, most being found in less than 10 localities known on the island.

Related to the abundance is the frequency in which a taxon is recorded in each pond. The results with regard to taxa in the inundation area can be seen in Table 2. Most of the taxa are found in less than 5 ponds $(68 \%)$. And only 14 taxa are present in more than 10 . These more common plants are not exclusive to this habitat, but are also found in other habitats that share factors of extreme conditions of inundation and drought like seasonal streams or the margins of marshlands. Among these more frequent plants are the only two endemics that have been found in the inundation area: Romulea assumptionis and Polygonum romanum subsp. balearicum, both Gymnesian endemics.

\section{Chorology}

The chorological pattern of the plants recorded is quite similar to that of all the flora on the island (Tab. 3). Plants with a distribution limited to the area 


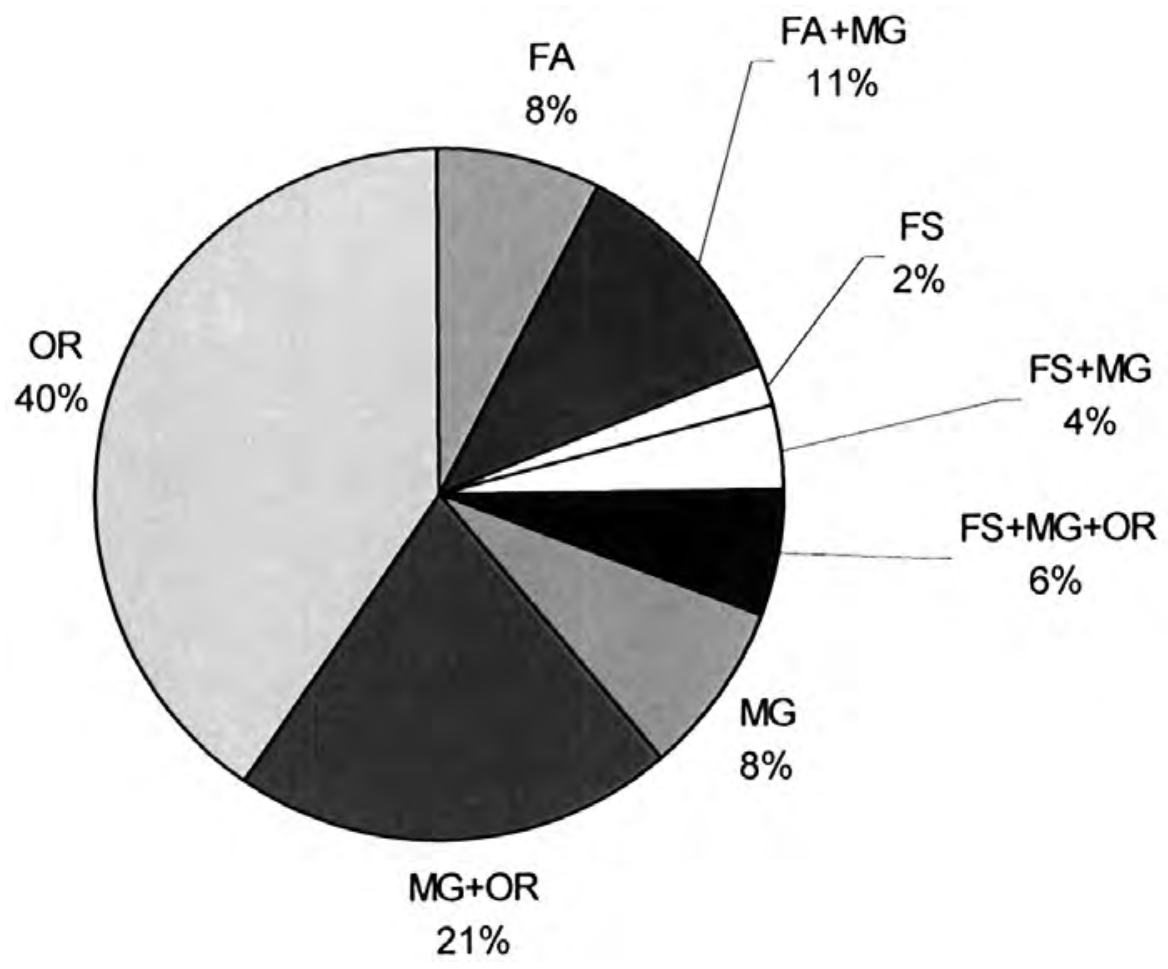

Fig. 5. Distribution of the taxa within the differents zones of the pond area. FA: aquatic phase of the inundation area; FS: dry phase of the inundation area; MG: marginal area; OR: terrestrial vegetation around the pond.

Table 2. Most frequent taxa in the temporary ponds of Minorca.

\begin{tabular}{|l|c|}
\hline Taxon & Number of ponds \\
\hline Cynodon dactylon & 33 \\
\hline Lythrum hyssopifolia & 24 \\
\hline Mentha pulegium & 23 \\
\hline Plantago weldenii & 22 \\
\hline Eleocharis palustris & 16 \\
\hline Carex divisa & 15 \\
\hline Carex divulsa & 14 \\
\hline Agrostis stolonifera & 14 \\
\hline Rumex pulcher subsp. woodsii & 12 \\
\hline Polygonum romanum subsp. balearicum & 12 \\
\hline Aster squamatus & 11 \\
\hline Romulea assumptionis & 11 \\
\hline Polypogon maritimus subsp. maritimus & 10 \\
\hline Dittrichia viscosa subsp. viscosa & 10 \\
\hline
\end{tabular}

around the Mediterranean Sea (Stenomediterranean and Eurimediterranean) are the most important group, with an even higher representation than all the flora on the island. Other groups like Atlantics and widely distributed plants also show a significant increase in their representation. Exotic and narrowly distributed species have a significant decrease instead. This data leads us to believe that vegetation of the temporary ponds is typically Mediterranean and shows a low rate of specificity in its distribution rate.

If we repeat the same analysis restricted to the inundation area, the information provided changes greatly. Now widespread (cosmopolitan, subcosmopolitan) taxa are the most significant group. Those strictly Mediterranean decrease to less than a half, however plants with a wider distribution (eurimediterranean) maintain a high representation, and those with a preference for cooler or wetter habitats (Atlantics) become even more important. These results agree with some common characteristics of aquatic habitats where long-distance dispersed species are most common due to the presence of active dispersals like migrant birds. But the anthropic origin of most of these species has also been under discussion (Bauder, 2000). The data from the taxa in the inundation area reveal another significant change. Now the alien species, mainly from America, are more important. This fact opposes the observations made in the same habitat in other regions like California where temporary ponds are said to have some resistance to plant invasions (Holland \& Jain, 1988; Cox, 1999). The contrasting results in the chorology of the 
Table 3. Distribution (\%) of chrological types within the taxa of the inundation area, the whole pond area and the vascular flora of Minorca (Fraga \& al., 2004).

\begin{tabular}{|l|c|c|c|}
\hline Chorological type & Inundation area & Whole pond area & Flora of Minorca \\
\hline Africa & 0 & 0,3 & 4,7 \\
\hline America & 8,4 & 2,8 & 1,3 \\
\hline Asia & 0,9 & 0,3 & 4,6 \\
\hline Atlantics & 9,3 & 7,3 & 1,5 \\
\hline Boreal & 1,9 & 1,4 & 10,1 \\
\hline Wide distribution & 26,2 & 13,0 & 6,3 \\
\hline Endemics & 0,9 & 4,0 & 6,4 \\
\hline Eurasiat. & 5,6 & 4,2 & 22,2 \\
\hline Euri-medit. & 19,6 & 24,5 & 5,7 \\
\hline Medit.-Turan. & 6,6 & 6,3 & 4,6 \\
\hline Paleotemp. & 5,6 & 5,1 & 28,7 \\
\hline Esteno-medit. & 12,1 & 30,2 & 1,1 \\
\hline Tropical & 2,8 & 0,6 & \\
\hline
\end{tabular}

flora for the whole studied area and that restricted to the inundation area, show again clear differences between these two parts.

\section{Life forms}

The representation of Raunkiaer's life forms (Table 4) reveals some interesting information about the characteristics of the vascular flora associated to this habitat. In the spectrum of the entire pond area the values are quite similar to those of the vascular flora on the island. That is, herbaceous plants are the most significant groups, especially the short lived ones (therophytes). Also woody plants (chamaephytes and phanerophytes) have some importance, but again there are extreme changes when considering only the inundation area. Now the annual plants are still the most notable group, with a value similar to that of the vascular flora on the island, but representation of woody forms decrease dramatically and, as could be expected, aquatic plants (hydrophytes) show a dramatic increase. Herbaceous perennial plants also show a significant increase in their representation.

These results, although somewhat predictable, are illustrative of the differences in vegetation among the different zones related to the temporary pond. The predominance of therophytes in the three analyses can be explained by their importance in the whole Mediterranean area as a consequence of the xeric character of its climate (Orshan \& al., 1988; Danin \& Orshan, 1990; Floret \& al., 1990; Heywood, 1995) or as another consequence of human influence (Fraga \& al., 2004). But in the inundation area there may be another explanation. Unlike the flora as a whole, where predominance of annuals seems to be a feature of the Mediterranean region (Madon \& Médail, 1997), tem-

Table 4. Representation (\%) of each Raunkiaer life form within the taxa of the inundation area, the whole pond area and the vascular flora of Minorca (Fraga \& al., 2004).

\begin{tabular}{|l|c|c|c|}
\hline Life form & Inundation area & Whole pond area & Flora of Minorca \\
\hline Chamaephytes & 2,8 & 8,6 & 11,4 \\
\hline Geophytes & 9,3 & 8,4 & 11,7 \\
\hline Hemicryptophytes & 26,2 & 22,3 & 3,6 \\
\hline Hydrophytes & 15,9 & 4,7 & 1,1 \\
\hline Lianas & 0 & 2,0 & 8,9 \\
\hline Phanaerophytes & 1,9 & 7,5 & 44,3 \\
\hline Therophytes & 43,9 & 46,5 & \\
\hline
\end{tabular}


porary ponds show a predominance of this life form in other regions like California (Zedler, 1987; Holland \& Jain, 1988). Thus, in the inundation area this result can be explained by some specific characteristics of this habitat that also favour this life form. These characteristics may be the dynamism and irregularity of hidroperiods in the time or the irregularity of the borders of the inundation area. The physical and environmental conditions created by both phenomena are more suitable for plants with a short life span than for those with a long one. The increase of hemicryptohytes may be attributed to similar reasons. These herbaceous perennials prefer open spaces, with few wood species, like those created by water dynamism in temporary ponds, also more resilient to periods of inundation.

This data about life forms again shows a differentiation between the flora of the inundation area of temporary pools and that of the surrounding area or with respect to the all the flora on the island.

\section{Exotic species}

Alien or exotic species are a group of plants that must be considered for their probable negative impact on the habitat as some can develop invasive behaviour. Several studies have shown the importance of alien species in the conservation of temporary ponds (Bauder, 1996; Gerhardt \& Collinge, 2003; Zedler \& Black, 2004). In fact, alien invasive plants are seen as a main threat for the conservation of this habitat within the LIFE BASSES project. Ten naturalised alien species have been found in the inundation area of the ponds. None of them are hydrophytes, so all their growing seasons coincide mainly during the dry phase. All but two are therophytes: Amaranthus albus, A. bybridus, A. retroflexus, A. viridis, Aster squamatus, Chamaesyce postrata, Conyza sumatrensis and Heliotropium curassavicum. The two hemicryptophytes: Arundo donax and Paspalum paspalodes have a clearly invasive behaviour. The latter is the most widespread in this habitat. The aggressive capacity of this species as an invader has been seen in other aquatic habitats (Aguiar \& al., 2001; 2005; Bernez \& al., 2005; 2006) and in some ponds it has completely changed the ecology forming a monotypic vegetation at the expense of the native plants.

\section{Conclusions}

The vascular flora associated to Mediterranean temporary ponds in Minorca has two main groups of taxa, those that grow without the direct influence of the standing water, and those that grow within the inundation area, in the aquatic or even in the dry phase.
The former show characteristics similar to the flora of the entire island in terms of abundance, life forms and chorology. On the other hand, the taxa that usually grow in the inundation area have a different pattern within the same parameters. Despite the alternation between the inundation and drought phases, the flora of the inundation area has a vegetation whose primary traits are similar to those of other aquatic habitats, i.e. the importance of widely distributed taxa or the predominance of herbaceous life forms.

\section{Acknowledgements}

This project has been developed within the LIFE NATURE project LIFE05/NAT/ES/000058 "Management and conservation of Mediterranean temporary ponds on the island of Minorca" (LIFE BASSES, www.cime.es/lifeflora), co-financed by the European Union and the Consell Insular de Menorca.

\section{References}

Aguiar, F.C., Ferreira, M.T. \& Moreira, I. 2001. Exotic and native vegetation establishment following channelization of a western Iberian river. Regulated Rivers: Research \& Management 17: 509-526.

Aguiar, F.C., Ferreira, M.T., Albuquerque, A. \& Bernez, I. 2005. Invasibility patterns of knotgrass (Paspalum distichum) in Portuguese riparian habitats. Weed Technology 19: 509-516.

Barbour, M., Solomeshch, A., Witham, C., Holland, R., Macdonald, R., Cilliers, S., Molina, J.A., Buck, J. \& Hillman, J. 2003. Vernal pool vegetation of California: variation within pools. Madroño 50: 129-146.

Barry, S.J. 1998. Managing the Sacramento Valley vernal pool landscape to sustain the native flora. In: Witham, C.W., Bauder, E.T., Belk, D., Ferren Jr., W.R. \& Ornduff, R. (eds.), Ecology, conservation and management of vernal pool ecosystems. Proceedings from a 1996 conference: 236-240. California Native Plant Society. Sacramento.

Baskin, Y. 1994. California's ephemeral vernal pools may be a good model for speciation. Bioscience 44: 384-388.

Bauder, E.T. 1997. Exotics in the southern California vernal pool ecosystem. In: Lovich, J., Randall, J. \& Kelly, M. (eds.), Proceedings of the California Exotic Pest Plant Council Symposium 1996: 52-55. San Diego, CA.

Bauder, E.T. 2000. Inundation effects on small-scale distributions in San Diego, California vernal pools. Aquatic Ecology 34: 4361.

Bernez, I., Ferreira, M.T., Albuquerque, A. \& Aguiar, F. 2005. Relations between river plant richness in the Portuguese floodplains and the widespread water knotgrass (Paspalum paspalodes). Hydrobiologia 551: 121-130.

Bernez, I., Aguiar, F., Violle, C. \& Ferreira, T. 2006. Invasive river plants from Portuguese floodplains: What can species attributes tell us? Hydrobiologia 570: 3-9.

Cox, G.W. 1999. Alien species in North America and Hawaii. Impacts on natural ecosystems. Island Press. Washington, DC.

Crowe, E.A, Busacca, A.J., Reganold, J.P. \& Zamora, B.A. 1994. Vegetation zones and soil characteristics in vernal pools in the channeled scrubland of Eastern Washington. Great Basin Naturalist 54: 234-247.

Danin, A. \& Orshan, G. 1990. Sur les types biologiques bota- 
niques en tant que stratégie adaptative (cas des thérophytes). In: Barbault, R., Blandin, P. \& Meyer, J.A. (eds.), Recherches d'écologie théorique: les stratégies adaptatives: 89-114. Maloine. Paris.

Floret, C., Galan, M.J., Le Floc'h, E., Orshan, G. \& Romane, F. 1990. Growth forms and phenomorphology traits along an environmental gradient: tools for studying vegetation. Journal of Vegetation Science 1: 71-80.

Fraga i Arguimbau, P., Mascaró Sintes, C., Carreras Martí, D., Garcia Febrero, O., Pallicer Allés, X, Pons Gomila, M., Seoane Barber, M. \& Truyol Olives, M. 2004. Catàleg de la flora vascular de Menorca. IME. Maó.

Fraga i Arguimbau, P., Cardona Pons, E., Allès Marquès, M., Torres Moll, E., Juaneda Franco, J., Estaún Clarisó, I. \& Mascaró Pons, J. 2007. Gestió i conservació de llacunes temporànies de Menorca. Actes del simposi científic sobre gestió i conservació de llacunes temporànies mediterrànies. Banyoles, 19, 20 i 21 de març de 2007. Banyoles (in press).

Gauthier, P., Grillas, P. \& Cheylan, M. 2004. Threats to Mediterranean temporary pools. In: Grillas, P., Gauthier, P., Yavercovski, N. \& Perennou, C. (eds.), Mediterranean temporary pools. Vol. 1. Issues relating to conservation, functioning and management: 63-70. Station biologique de la Tour du Valat. Arles.

Gerhardt, F. \& Collinge, S.K. 2003. Exotic plant invasions of vernal pools in the Central Valley of California, USA. Journal of Biogeography 30: 1043-1052.

Grillas, P. 2004. Introduction. In: Grillas, P., Gauthier, P., Yavercovski, N. \& Perennou, C. (eds.), Mediterranean temporary pools. Vol. 1. Issues relating to conservation, functioning and management: 11-12. Station biologique de la Tour du Valat. Arles.

Heywood, V.H. 1995. The mediterranean flora in the context of world diversity. Ecologia Mediterranea 21: 11-18.

Holland, R.F. \& Dains, V.I. 1990. The edaphic factor in vernal pool vegetation. In: Ikeda, D.H. \& Schlising, R.A. (eds.), Vernal pool plants. Their habitat and biology: 31-48. Studies from the Herbarium 8. California State University. Chico.

Holland, R.F. \& Jain, S.K. 1981a. Insular biogeography of vernal pools in the Central Valley of California. American Naturalist 117: 24-37.

Holland, R.F. \& Jain, S.K. 1981b. Spatial and temporal variation in plant species diversity of vernal pools. In: Jain, S. \& Moyle, P. (eds.), Vernal pools and intermittent streams: 198-209. Insititute of Ecology Publication, 28. University of California. Davis.

Holland, R.F. \& Jain, S.K. 1988. Vernal Pools. In: Barbour, M.G. \& Major, J. (eds.), Terrestrial vegetation of California: 515-533. John Wiley and Sons. New York.

Jones \& Stokes Associates, Inc. 1990. Sacramento County Vernal
Pools: Their distribution, classification, ecology and management. Prepared for County of Sacramento planning and community development department. Sacramento.

Keeley, J.E. \& Zedler, P.H. 1998. Characterization and global distribution of vernal pools. In: Witham, C.W., Bauder, E.T., Belk, D., Ferren Jr., W.R. \& Ornduff, R. (eds.), Ecology, conservation and management of vernal pool ecosystems. Proceedings from a 1996 conference: 1-14. California Native Plant Society. Sacramento.

Madon, O. \& Médail, F. 1997. The ecological significance of annuals on a Mediterranean grassland (Mt Ventoux, France). Plant Ecology 129: 189-199.

Orshan, G., Le Floc'h, E., Le Roux, A. \& Montenegro, G. 1988. Plant phenomorphology as related to summer drought Mediterranean type ecosystems. In: Di Castri, F., Floret, C., Rambal, S. \& Roy, J. (eds.), Time scales and water stress: 111-123. IUBS Press. Paris.

Pretus, J.L. 1990. Inventari de les zones humides de Menorca. Institut Menorquí d'Estudis. (unpublished).

Rhazi, L., Grillas, P., Toure, A.M. \& Ham, L.T. 2001. Impact of land use in catchment and human activities on water, sediment and vegetation of Mediterranean temporary pools. C.R. Académie des Sciences de Paris. Sciencies de la vie 324: 165. 177.

Smith, D.W. \& Verrill, W.L. 1998. Vernal pool-soil-landform relationships in the Central Valley, California. In: Witham, C.W., Bauder, E.T., Belk, D., Ferren Jr., W.R. \& Ornduff, R. (eds.), Ecology, conservation and management of vernal pool ecosystems - Proceedings from a 1996 Conference: 15-23. California Native Plant Society. Sacramento.

Stone, R.D. 1990. California's endemic vernal pool plants: some factors influencing their rarity and endangerment. In: Ikeda, D.H. \& Schlising, R.A. (eds.), Vernal pool plants: their habitat and biology: 89-107. Studies from the Herbarium 8. California State University. Chico.

Yavercovski, N., Grillas, P., Paradis, G. \& Thiéry, A. 2004. Biodiversity and conservation issues. In: Grillas, P., Gauthier, P., Yavercovski, N. \& Perennou, C. (eds.), Mediterranean temporary pools. Vol. 1. Issues relating to conservation, functioning and management: 13-35. Station biologique de la Tour du Valat. Arles.

Zedler, P.H. 1987. The ecology of southern California vernal pools: a community profile. Biological Report 85 (7.11.). Prepared for USFWS, National Wetlands Research Center. Washington D.C.

Zedler, P.H., \& Black, C. 2004. Exotic plant invasions in an endemic-rich habitat: The spread of an introduced Australian grass, Agrostis avenacea J.F. Gmel., in California vernal pools. Austral Ecology 29: 537-546. 


\begin{tabular}{|c|c|c|c|c|c|c|c|c|c|c|c|c|c|c|c|c|c|c|c|c|c|c|c|c|c|c|}
\hline ỡ & $\times$ & $\times$ & & $\times$ & $\times$ & $\times$ & $\times$ & & $\times$ & $\times$ & $\times$ & $\times$ & $\times$ & $\times$ & $\times$ & $\times$ & $\times>>$ & \begin{tabular}{l|l}
$\times$ & $\times$ \\
\end{tabular} & $\times \quad \times$ & \begin{tabular}{c|c}
$x$ & $\times$ \\
\end{tabular} & $\times$ & & $\times$ & $\times$ & $\times$ & \\
\hline$\stackrel{W}{\Sigma}$ & & & $\times$ & $\times$ & & $\times$ & & & $\times$ & $\times$ & $\times$ & $\times$ & $\times$ & & $\times$ & $\times$ & & $\times$ & & $\times$ & & $\times$ & & & & $x$ \\
\hline น & & & & & & & & & $\times$ & $\times$ & $\times$ & $\times$ & & & & & & & & & & & & & & \\
\hline 氐 & & & $\times$ & & & & & $\times$ & & & & & & & & & & & & & & $\times$ & & & & \\
\hline
\end{tabular}

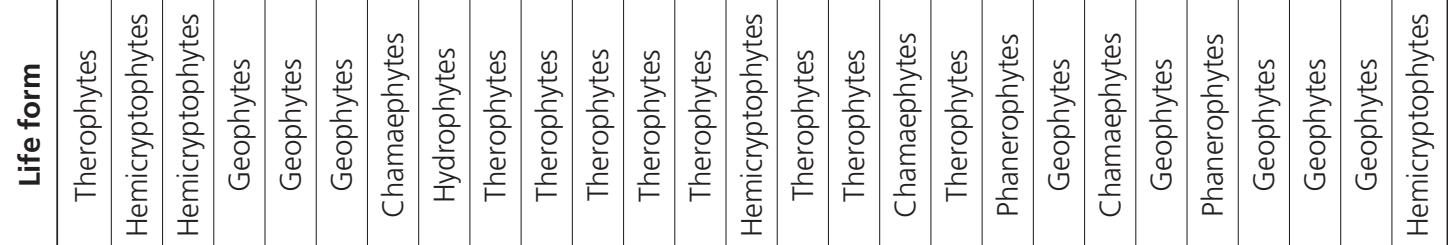

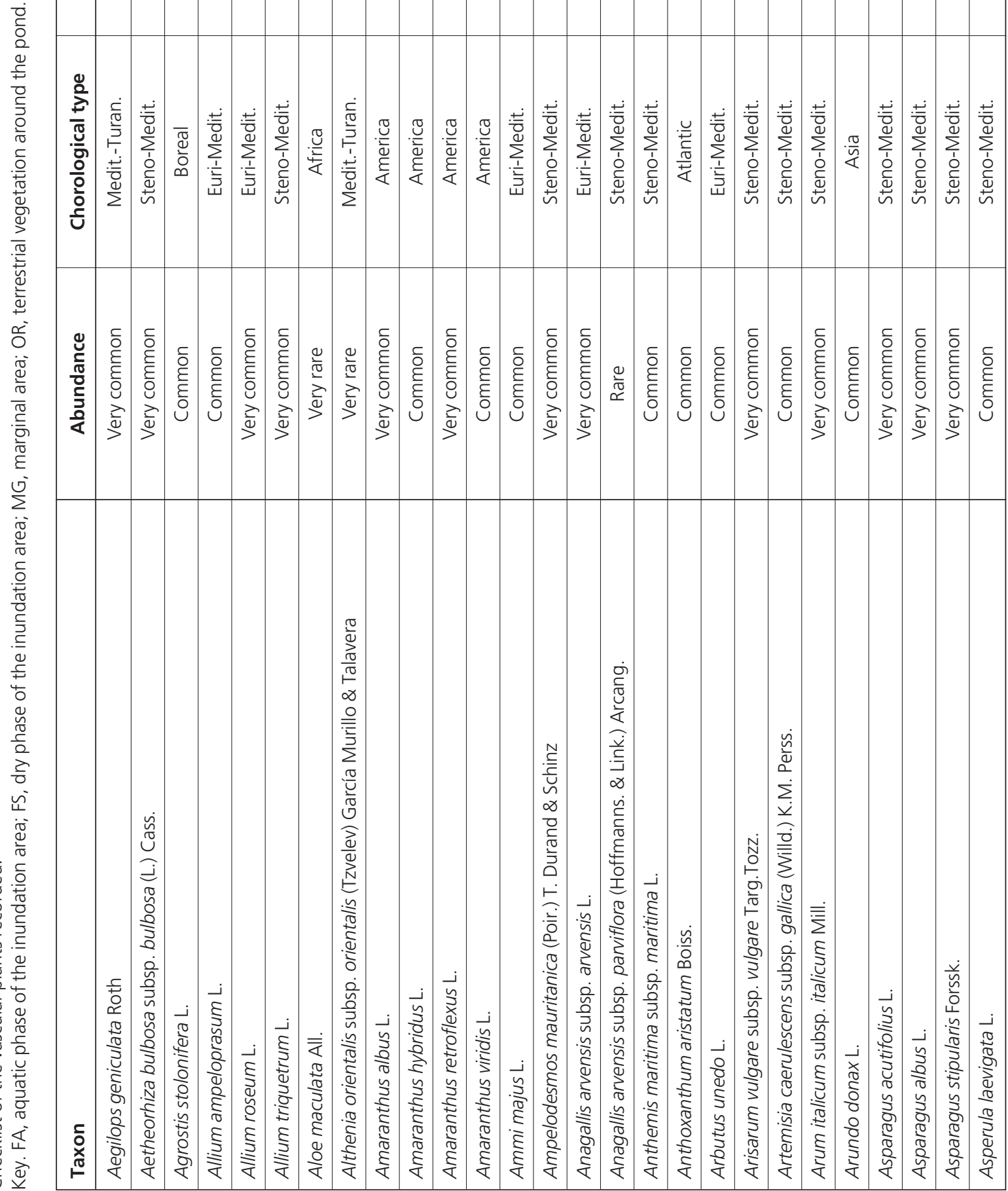




\begin{tabular}{|c|c|c|c|c|c|c|c|c|c|c|c|c|c|c|c|c|c|c|c|c|c|c|c|c|c|c|c|c|c|c|c|}
\hline वै & $\times$ & $\times$ & $\times$ & $\times$ & & $\times$ & $\times$ & $x$ & & $\times$ & $\times$ & $\times$ & $\times$ & $\times$ & $\times$ & $\times$ & $\times$ & $\times$ & $\times$ & $\times$ & $\times$ & $\times$ & & & & $\times$ & $\times$ & & & $\times$ & $x$ \\
\hline $\mathbb{O}_{\Sigma}$ & & & & & $x$ & $\times$ & $x$ & & & & & $\times$ & & & & & & & $\times$ & $\times$ & $\times$ & & & & & & & $\times$ & $\times$ & $\times$ & $x$ \\
\hline$\tilde{u}$ & & & & & $\times$ & & & & & & & & & & & & & & & & & & & & & & & & & & $\times$ \\
\hline$<$ & & & & & & & & & $\times$ & & & & & & & & & & & & & & $\times$ & $\times$ & $\times$ & & & $\times$ & $\times$ & & \\
\hline
\end{tabular}

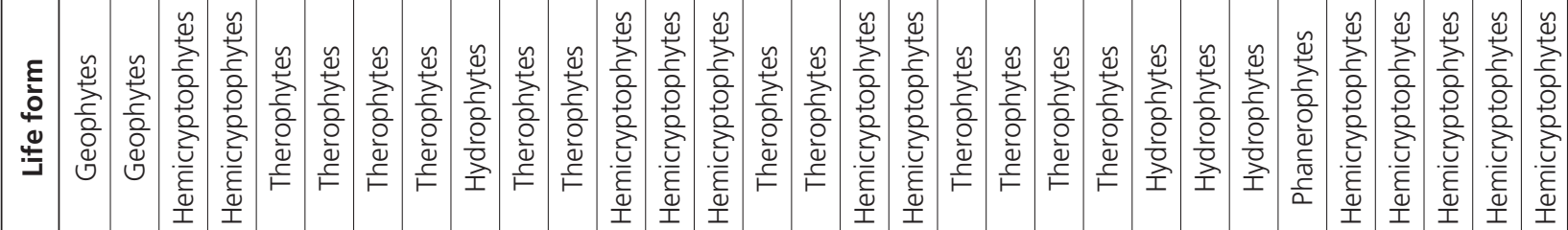

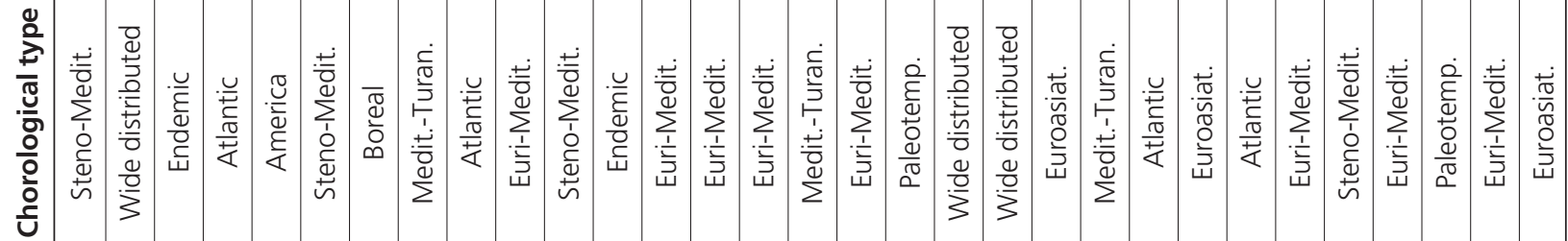

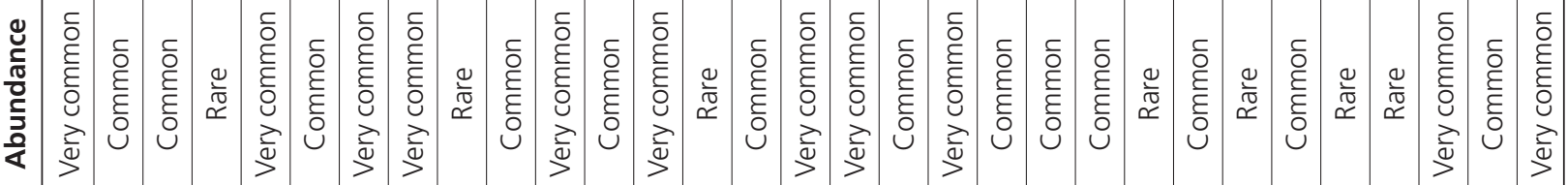




\begin{tabular}{|c|c|c|c|c|c|c|c|c|c|c|c|c|c|c|c|c|c|c|c|c|c|c|c|c|c|c|c|c|c|c|c|}
\hline 뜽 & $\times$ & $\times$ & $x$ & $\times$ & $\times$ & $\times$ & & & $\times$ & $x$ & $\times$ & $x$ & $x$ & $\times$ & $\times$ & $x$ & $x$ & $\times$ & $\times$ & $\times$ & $\times$ & $\times$ & & & $\times$ & $x$ & $\times$ & & $\times$ & $\times$ & \\
\hline$\sum^{0}$ & & & & & $\times$ & $\times$ & $\times$ & $\times$ & $\times$ & $\times$ & $\times$ & $\times$ & $\times$ & $\times$ & $\times$ & & & & & & $\times$ & $\times$ & & & $\times$ & $\times$ & & & $\times$ & $\times$ & $\times$ \\
\hline น & & & & & & & & $\times$ & $\times$ & $\times$ & $\times$ & $\times$ & $\times$ & & & & & & & & $\times$ & $\times$ & $\times$ & $\times$ & & & & $\times$ & $\times$ & & \\
\hline $\mathbb{4}$ & & & & & & & $\times$ & & & & & & & & & & & & & & & & & & & & & & & & $\times$ \\
\hline
\end{tabular}

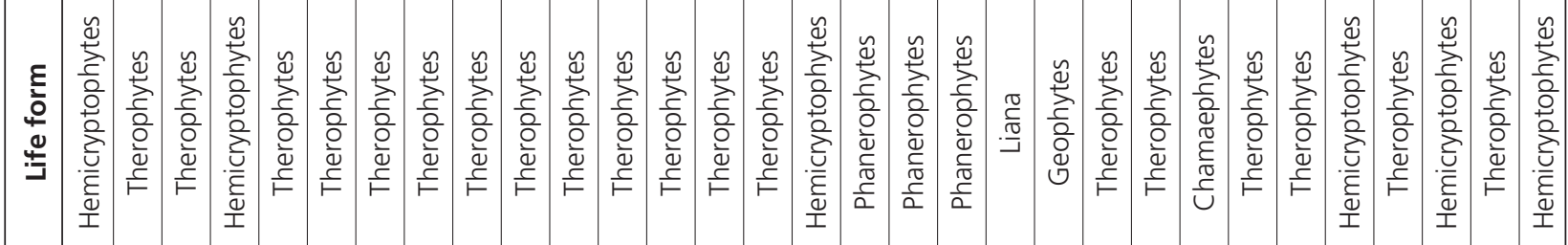

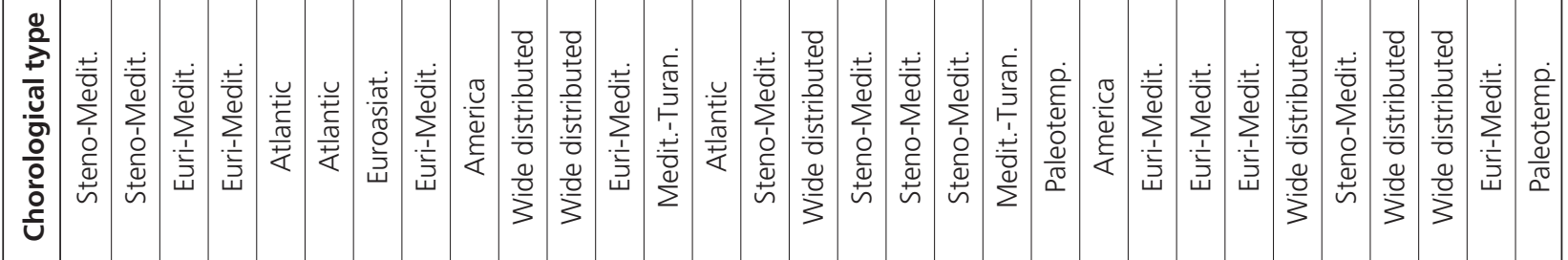

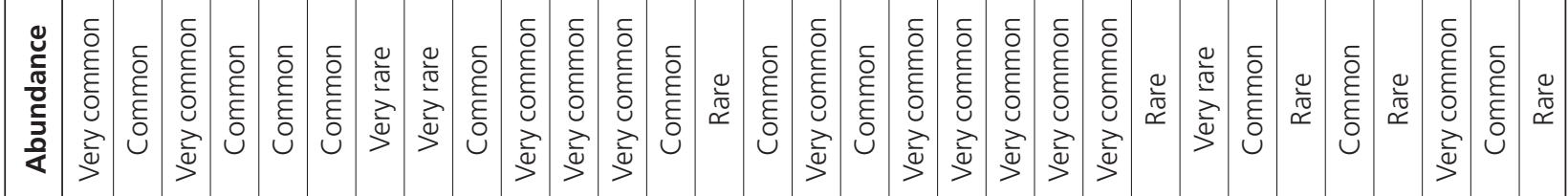

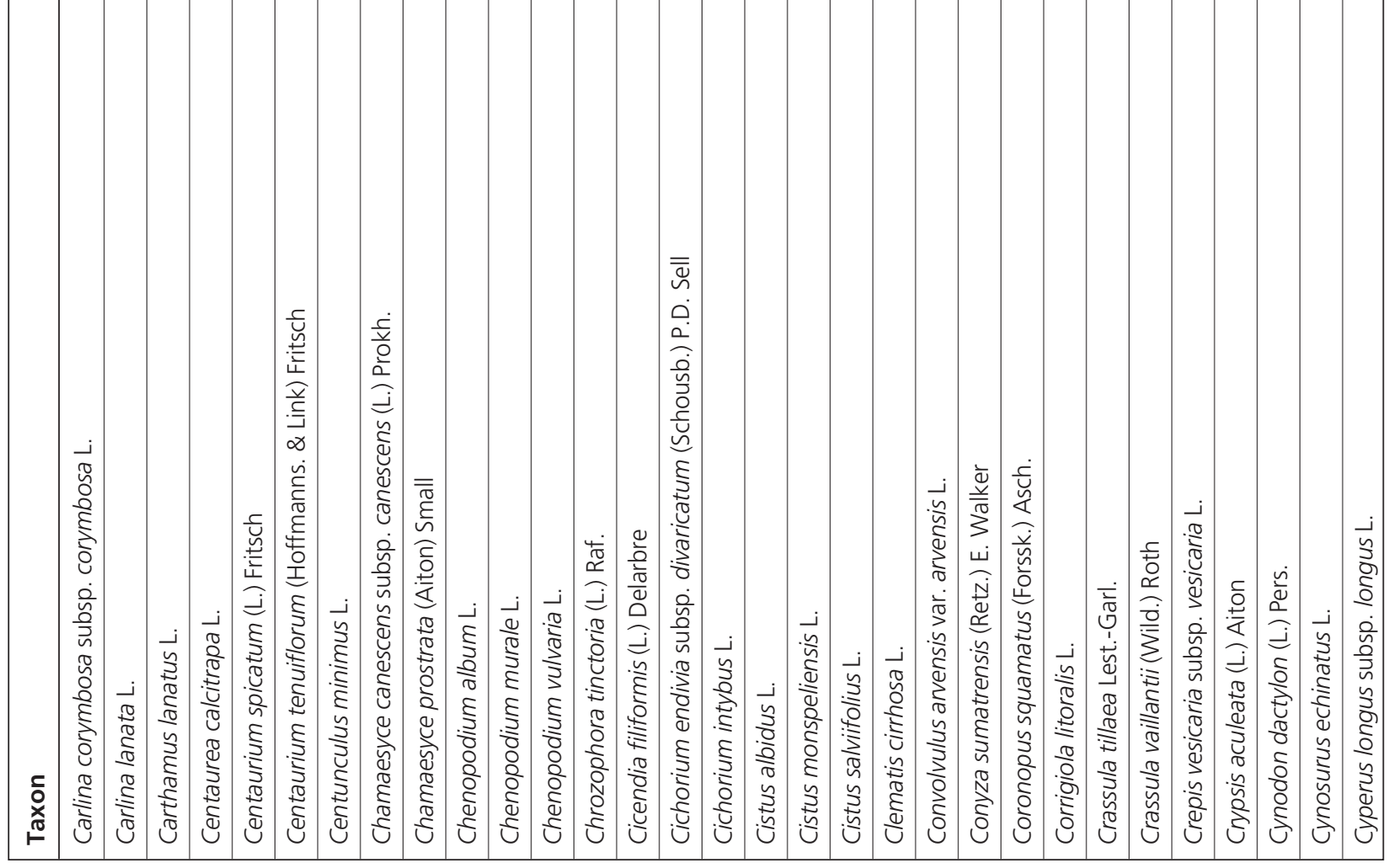




\begin{tabular}{|c|c|c|c|c|c|c|c|c|c|c|c|c|c|c|c|c|c|c|c|c|c|c|c|c|c|c|c|c|c|}
\hline ¿ّ & $\times$ & & $\times$ & $\times$ & $\times$ & & $\times$ & $\times$ & $\times$ & $\times$ & $\times$ & $\times>>$ & $\times$ & & & & $\times$ & & & & $\times \mid \times$ & $\times \quad \times$ & $\times$ & $\times$ & $\times$ & $\times>$ & $\times$ & $\times$ & \\
\hline$\sum^{0}$ & $\times$ & & & & & $\times$ & $\times$ & $\times$ & & & $\times$ & $>$ & $\times$ & & $\times$ & $\times$ & $\times$ & $\times$ & $\times$ & $\times$ & & & & $\times$ & & & & & \\
\hline น & & & & & & $\times$ & $\times$ & $\times$ & & & $\times$ & & & & & & & & & $x$ & & & & & & & & & \\
\hline$\varangle$ & & $x$ & & & & & & & & & & & $>$ & \begin{tabular}{l|l}
$\times$ & $\times$
\end{tabular} & $\times$ & $\times$ & & & & & & & & & & & & & $x$ \\
\hline
\end{tabular}

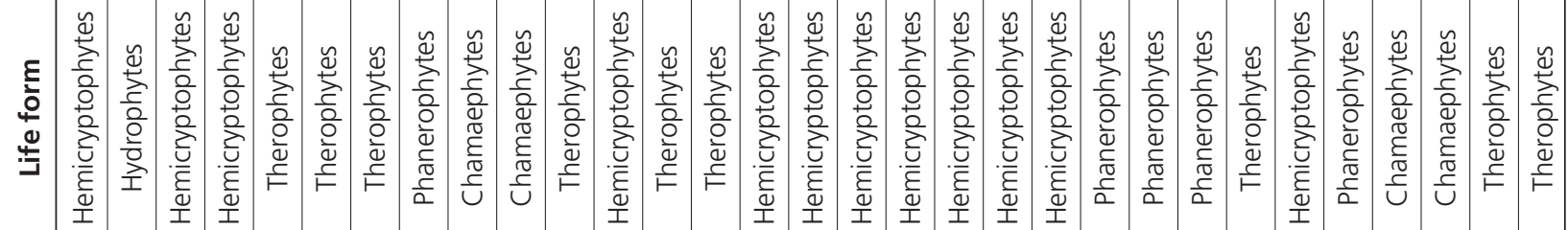

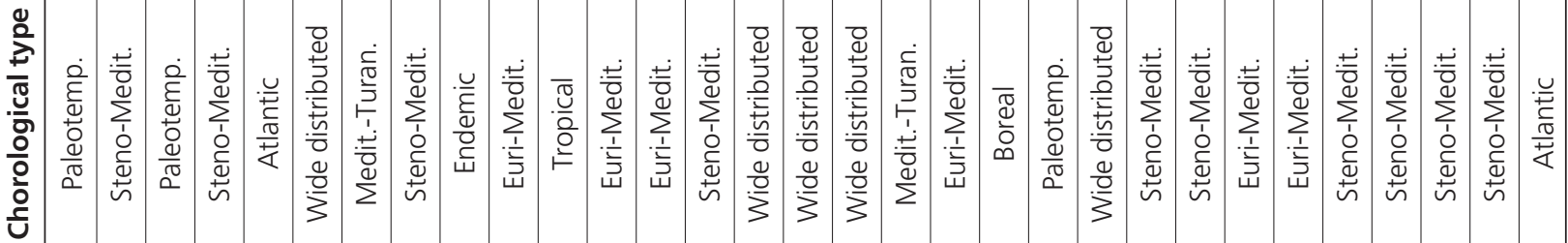

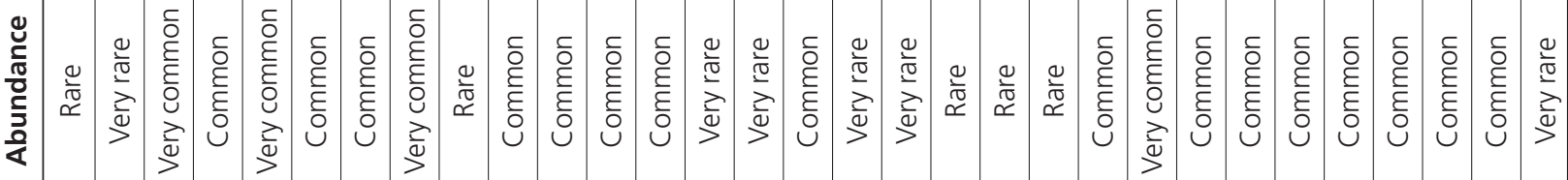

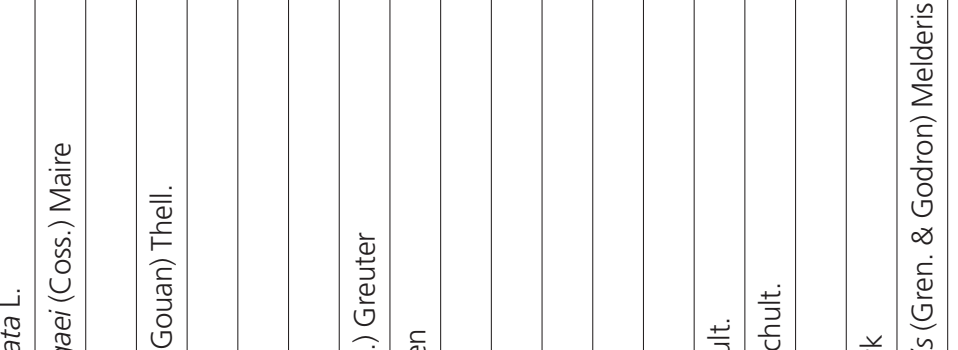

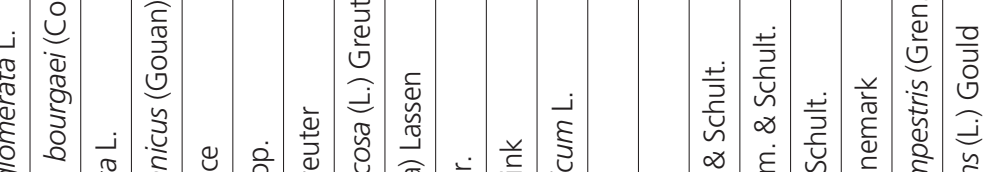

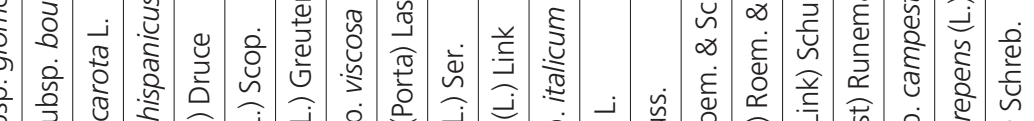

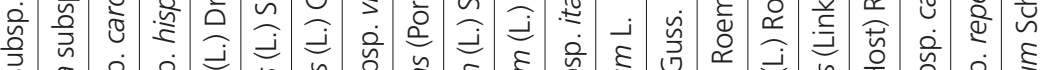

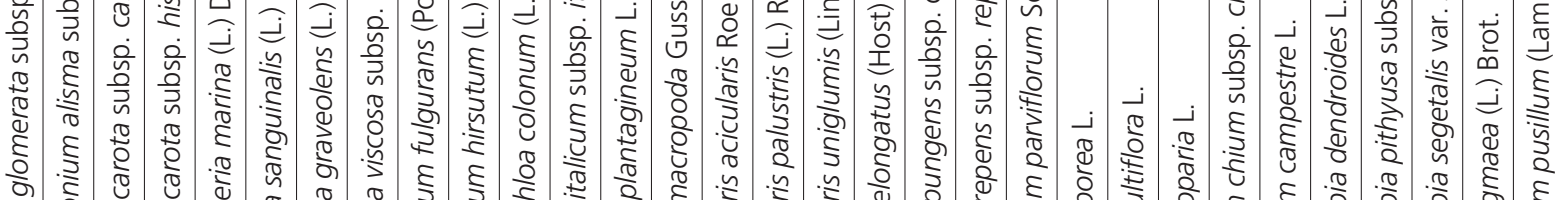

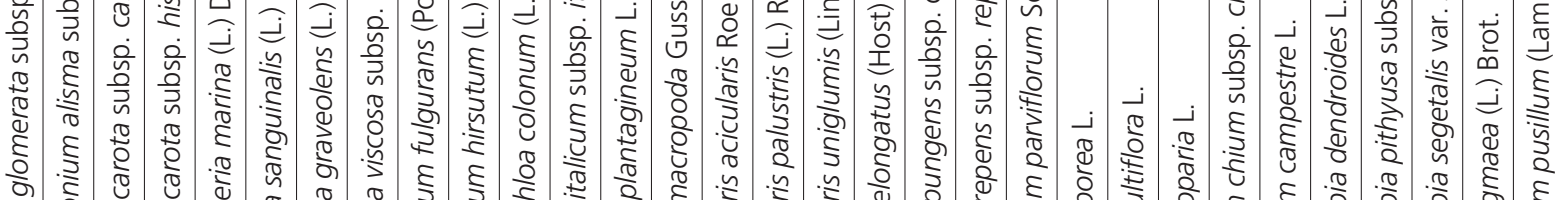

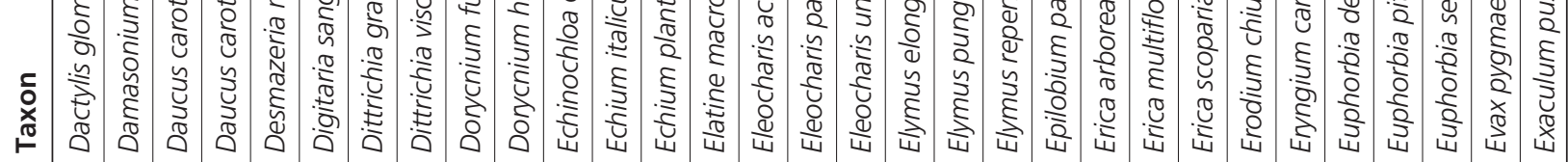




\begin{tabular}{|c|c|c|c|c|c|c|c|c|c|c|c|c|c|c|c|c|c|c|c|c|c|c|c|c|c|c|c|c|c|c|c|}
\hline 㰻 & $\times$ & $\times$ & $\times$ & $\times$ & & $\times$ & $\times$ & & $\times$ & $\times$ & $\times$ & $\times$ & $\times$ & $\times$ & $\times$ & $\times$ & & $\times$ & $\times$ & $\times$ & & $\times$ & & $\times$ & & $\times$ & $\times$ & $\times$ & $\times$ & $\times$ & $\times$ \\
\hline$\stackrel{\mathbb{N}}{\Sigma}$ & & $\times$ & $\times$ & $\times$ & & & & $\times$ & & $\times$ & $\times$ & $\times$ & $\times$ & & $\times$ & $\times$ & $\times$ & & & $\times$ & & $\times$ & & & $\times$ & $\times$ & $\times$ & & & & $\times$ \\
\hline 노 & & & & & $\times$ & & & & & & & & & & & & $\times$ & & & & $\times$ & $\times$ & $\times$ & & & & & & & & $\times$ \\
\hline 氐 & & & & & & & & $\times$ & & & & & & & & & & & & & & & & & & & & & & & \\
\hline
\end{tabular}

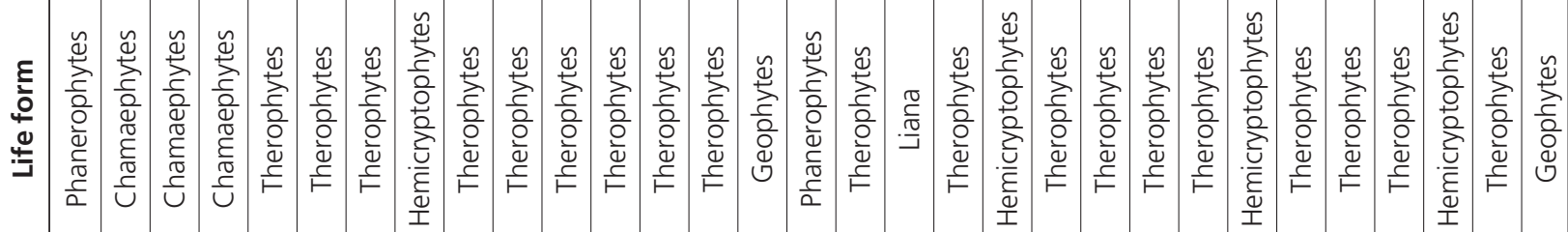

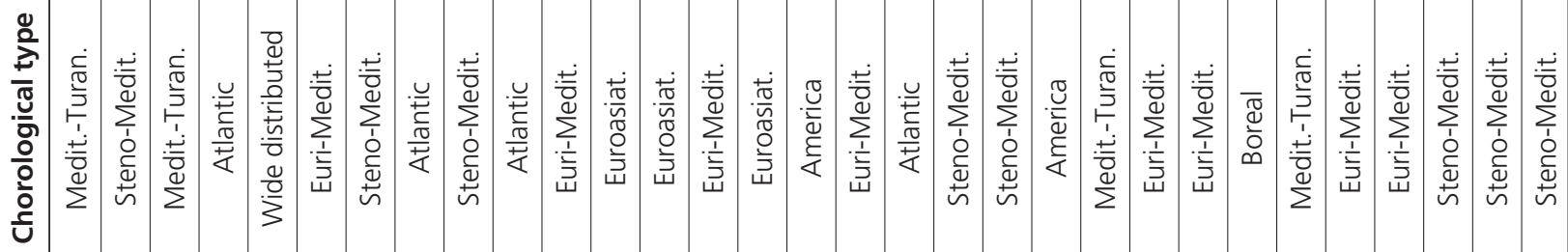

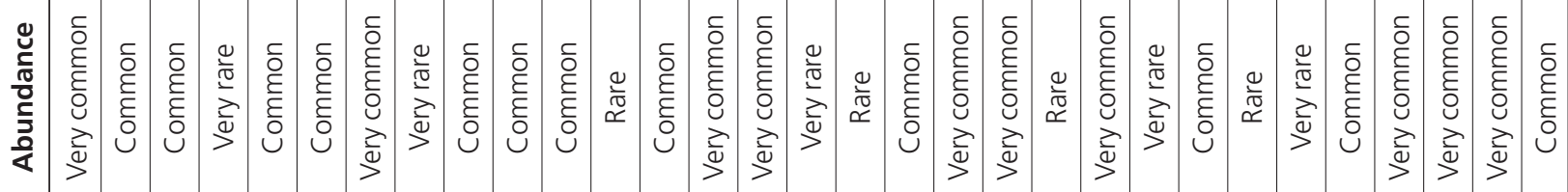

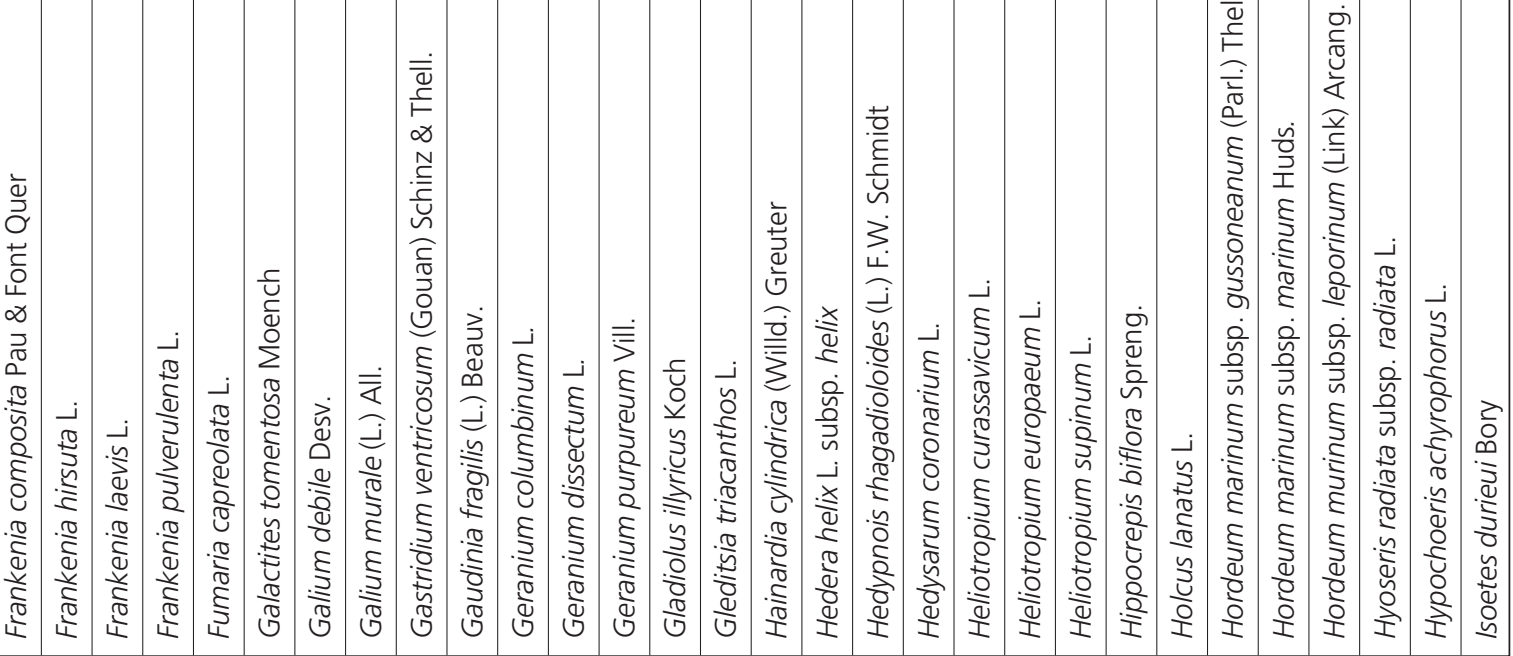




\begin{tabular}{|c|c|c|c|c|c|c|c|c|c|c|c|c|c|c|c|c|c|c|c|c|c|c|c|c|c|c|c|c|c|}
\hline 뜽 & & & & & & & & & & & & & $\times$ & $\times$ & $\times$ & $\times$ & $\times$ & $\times>$ & \begin{tabular}{l|l}
$\times$ & $\times$ \\
\end{tabular} & \begin{tabular}{l|l}
$\times$ & $\times$ \\
\end{tabular} & & & $\times>$ & \begin{tabular}{l|l}
$\times$ & $\times$ \\
\end{tabular} & \begin{tabular}{l|l}
$\times$ & $\times$ \\
\end{tabular} & $\times$ & $\times$ & $\times$ & $\times$ \\
\hline$\sum_{\Sigma}^{0}$ & $\times$ & & $\times$ & & $\times$ & $\times$ & $\times$ & $\times$ & $\times$ & $\times$ & $\times$ & $\times$ & & $\times$ & $\times$ & $\times$ & & $\times$ & & $\times$ & & & & $\times$ & & $\times$ & & & \\
\hline 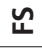 & & & & & & & & & & & & & & & & & & & & & & & & & & & & & \\
\hline 4 & $\times$ & $\times$ & $\times$ & $\times$ & & & $\times$ & & $\times$ & $\times$ & $\times$ & $x$ & & & & & & & & & $\times$ & $x$ & & & & & & & \\
\hline
\end{tabular}

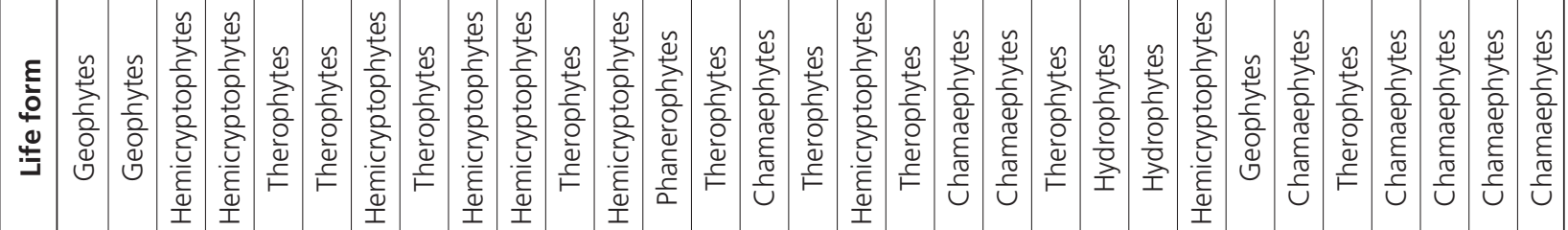

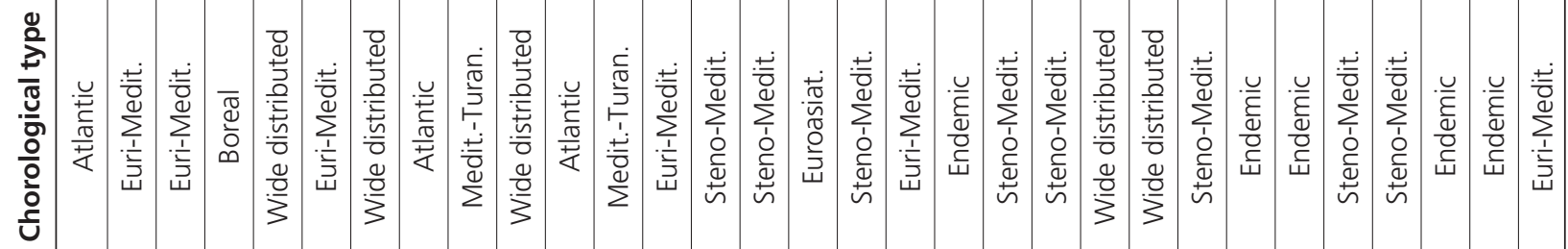

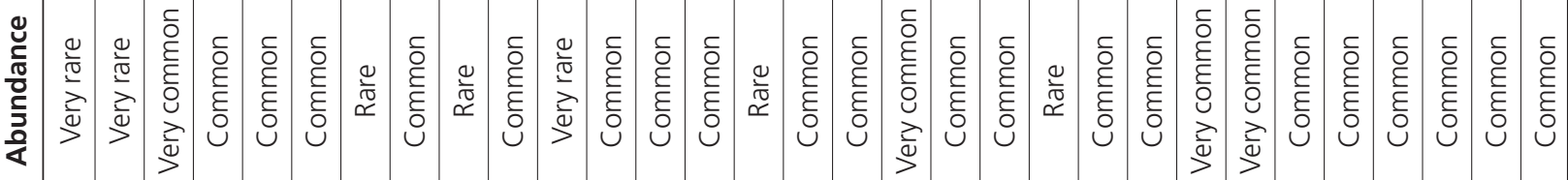

$\frac{\sqrt{3}}{\sqrt[5]{0}}$

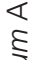

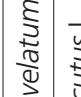

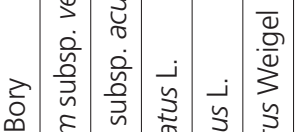

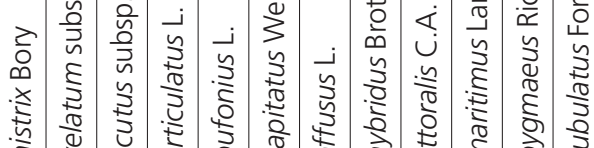

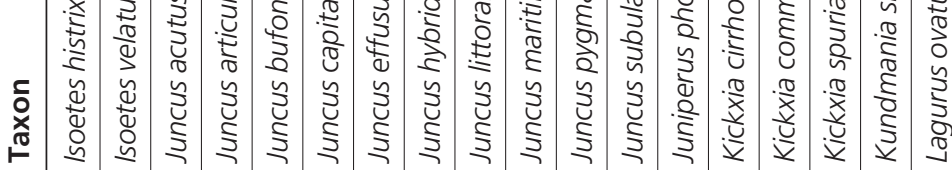

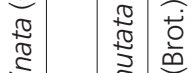

:

है

इ

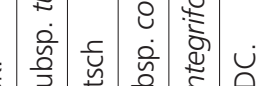

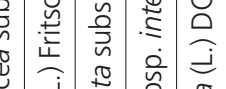

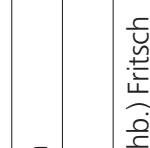

产

离

ज.

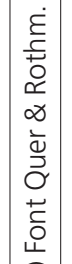

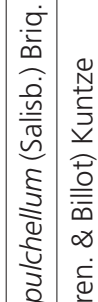

-

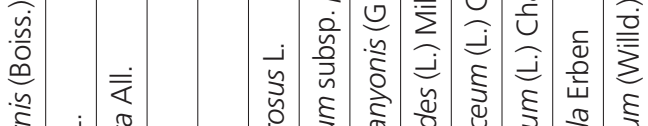

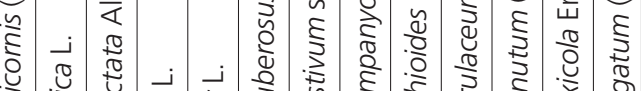

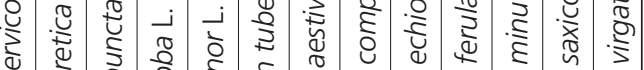

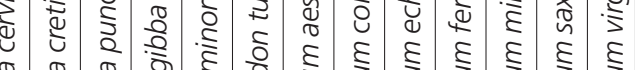

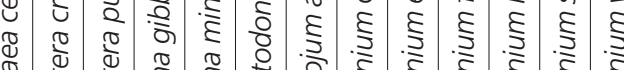




\begin{tabular}{|l|l|l|l|l|l|l|l|l|l|l|l|l|l|l|l|l|l|l|l|l|l|l|l|l|l|l|l|l|l|l|l|}
\hline$\stackrel{\circ}{\circ}$ & $\times$ & $\times$ & & $\times$ & $\times$ & $\times$ & $\times$ & $\times$ & $\times$ & & $\times$ & & & & & & & & & & & $\times$ & $\times$ & $\times$ & $\times$ & $\times$ & $\times$ & $\times$ & $\times$ & & $\times$ \\
\hline$\check{\Xi}$ & $\times$ & & $\times$ & & $\times$ & $\times$ & & & & $\times$ & & $\times$ & $\times$ & $\times$ & $\times$ & & $\times$ & $\times$ & $\times$ & & & $\times$ & $\times$ & $\times$ & & & & & & $\times$ & \\
\hline$\breve{u}$ & & & & & & & & & & & & & & & & & & & & & & & $\times$ & & & & & & \\
\hline$\overleftarrow{\iota}$ & & & $\times$ & & & & & & & $\times$ & & $\times$ & $\times$ & & & $\times$ & $\times$ & $\times$ & $\times$ & $\times$ & $\times$ & & & & & & & & & $\times$ & \\
\hline
\end{tabular}

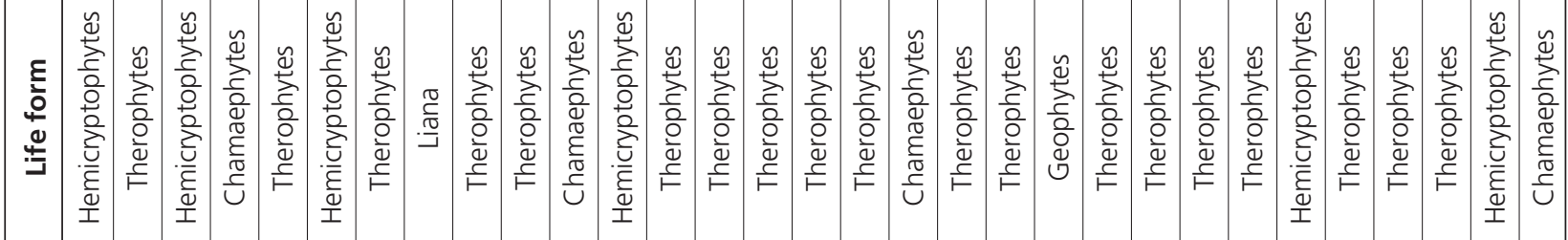

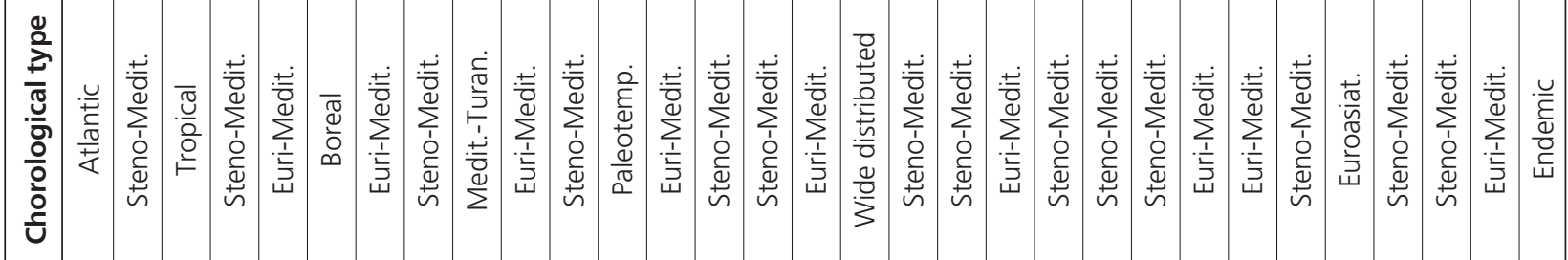

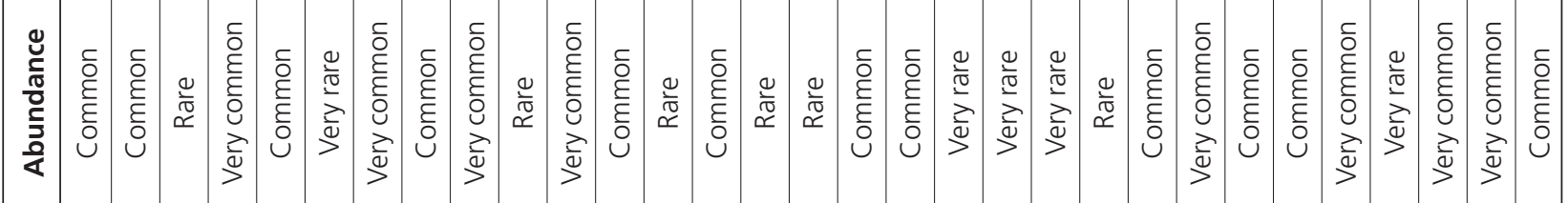

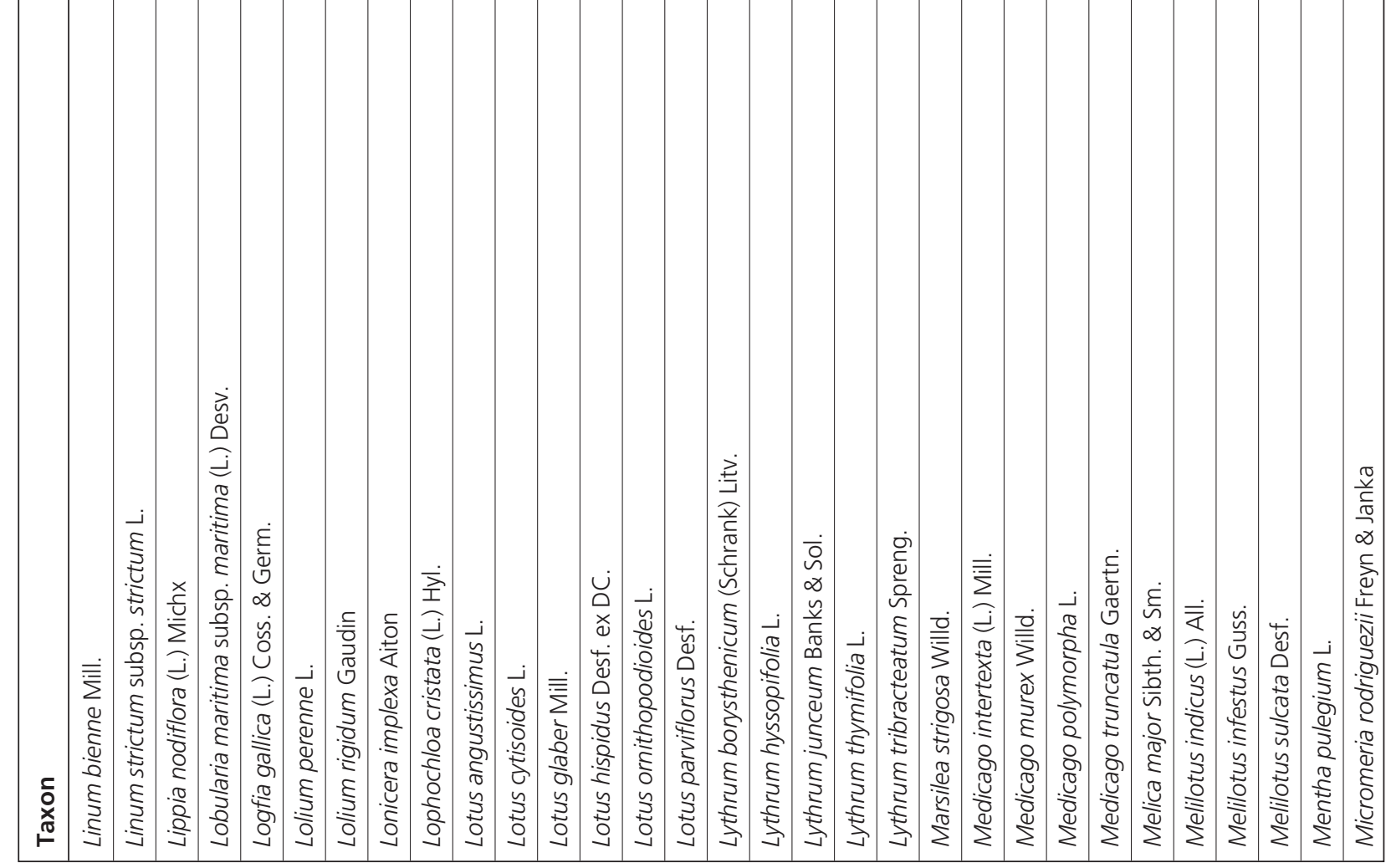




\begin{tabular}{|c|c|c|c|c|c|c|c|c|c|c|c|c|c|c|c|c|c|c|c|c|c|c|c|c|c|c|c|c|c|c|}
\hline 。̛̃ & & $\times$ & $\times$ & $\times$ & $\times$ & $\times$ & $\times$ & $\times$ & $\times$ & & $\times$ & $\times$ & $\times$ & $\times$ & & $\times$ & & & $\times$ & & $\times$ & $\bar{x}$ & & $\times$ & $\times$ & \begin{tabular}{l|l}
$\times$ & $>$
\end{tabular} & $\begin{array}{l}\times \\
\end{array}$ & & & $\times$ \\
\hline $\mathbb{N}_{\Sigma}^{J}$ & & $\times$ & & & & $\times$ & $\times$ & $\times$ & & $\times$ & & & & $\times$ & $\times$ & & $\times$ & $\times$ & $x$ & $\times$ & & $\times$ & & & & & $\times>$ & $x$ & & \\
\hline$\simeq$ & & & & & & & & & & & & & & & & & & & & & & & & & & & & & & \\
\hline$\underset{4}{\mathbb{4}}$ & $\times$ & & & & & & & & & & & & & & $\times$ & & & & & & & & $\times$ & & & & & & & \\
\hline
\end{tabular}

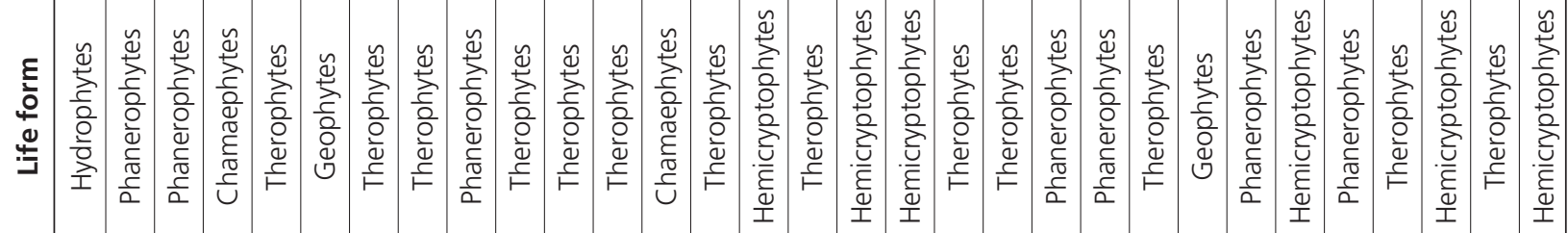

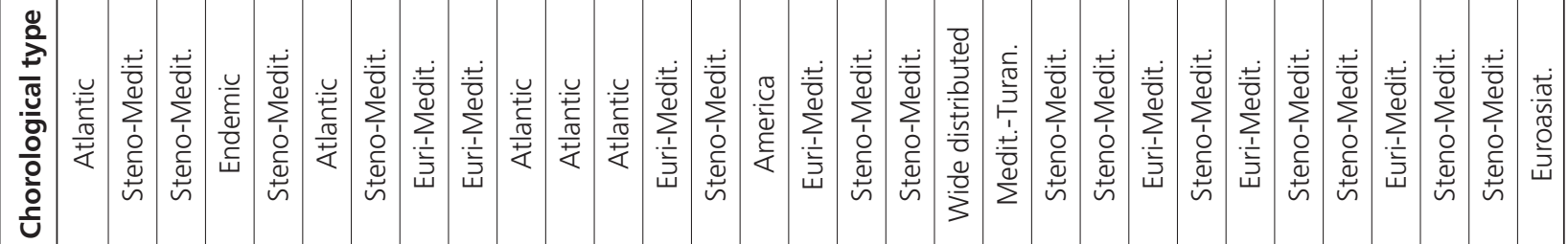

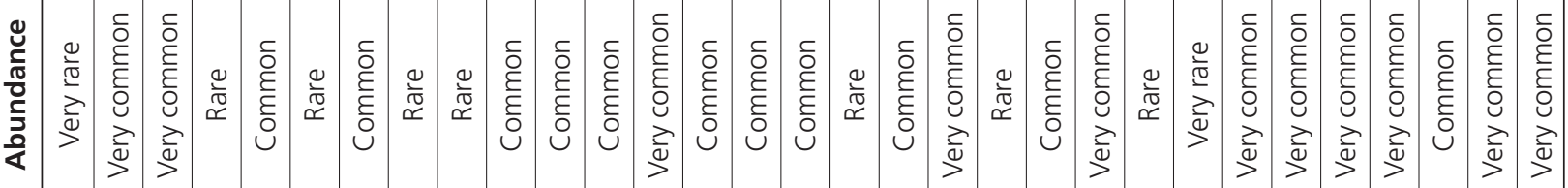

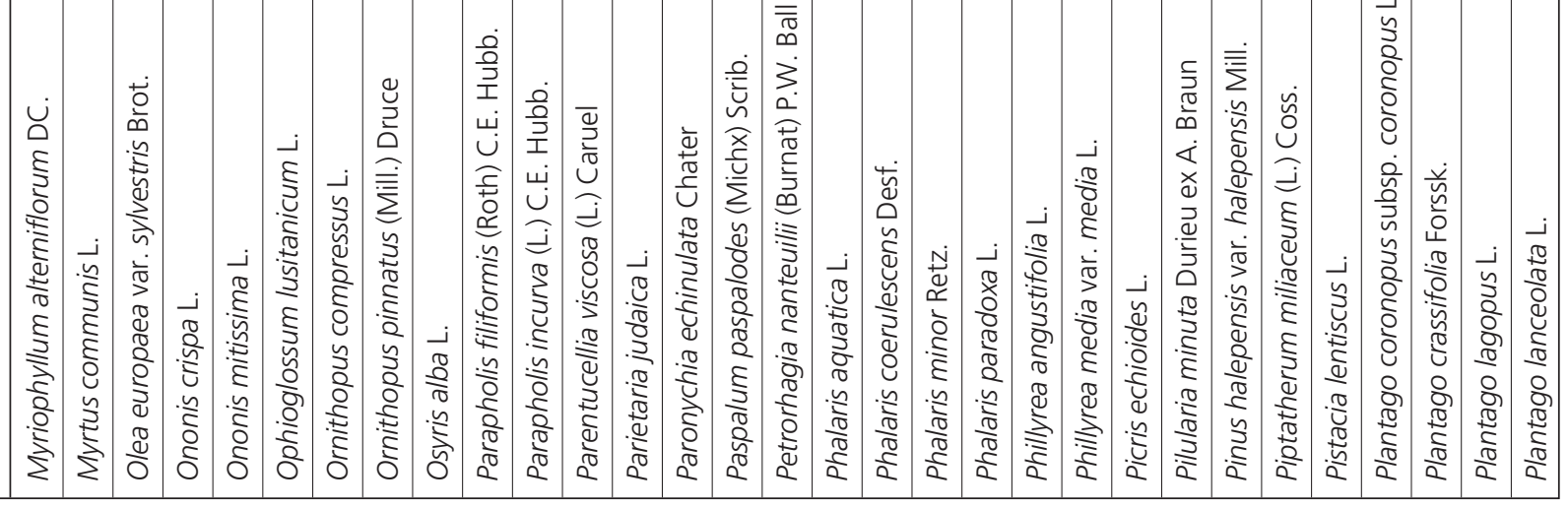




\begin{tabular}{|c|c|c|c|c|c|c|c|c|c|c|c|c|c|c|c|c|c|c|c|c|c|c|c|c|c|c|c|c|c|}
\hline 뜽 & & $\times$ & $\times$ & $\times$ & & & & & & $\times$ & & $\times$ & $\times$ & & & $\times$ & $>$ & $\times$ & & & & & & $\times>$ & \begin{tabular}{l|l}
$\times$ & $x$
\end{tabular} & \begin{tabular}{l|l}
$x$ & $x$
\end{tabular} & & $\times$ & $\times$ \\
\hline$\stackrel{\mathbb{N}}{\Sigma}$ & $\times$ & $\times$ & $\times$ & & $\times$ & $\times$ & $\times$ & $\times$ & $\times$ & $\times$ & & $x$ & & $\times$ & & & $\times>$ & $\times$ & $\times>$ & $\times$ & & $\times$ & $\times$ & & & $x$ & $x$ & & \\
\hline$\widetilde{4}$ & & $\times$ & & & $\times$ & $x$ & & & & $\times$ & & & & $\times$ & $\times$ & & & & & & & & & & & & & & \\
\hline$\varangle$ & & & & & & & $x$ & $x$ & & & $\times$ & & & & & & & & $\times>$ & $\times \quad \times$ & $\times \times$ & $\times$ & $\times$ & & & & $x$ & & \\
\hline
\end{tabular}

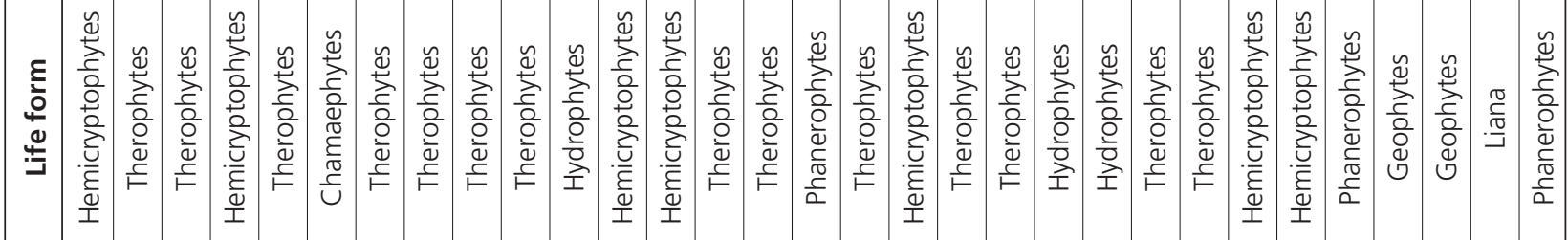

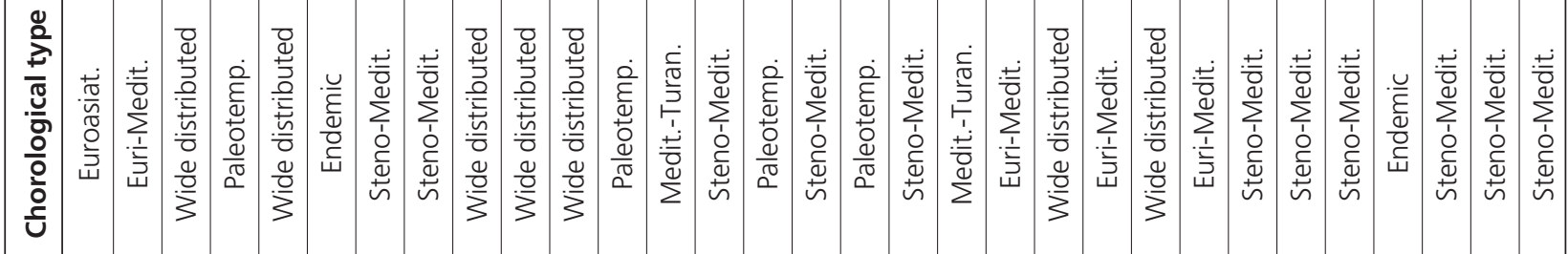

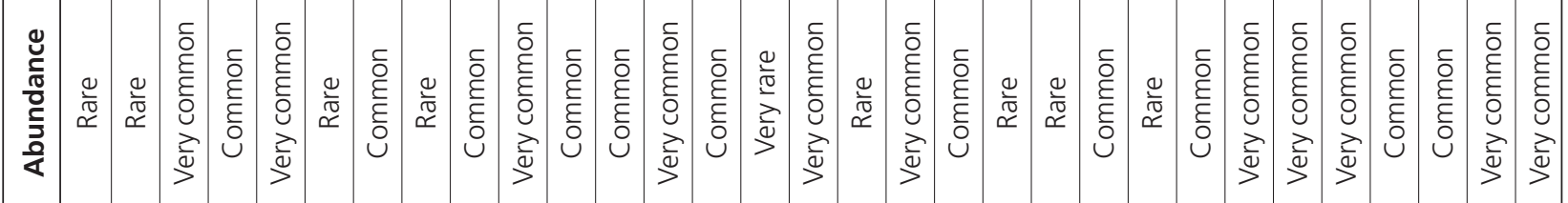

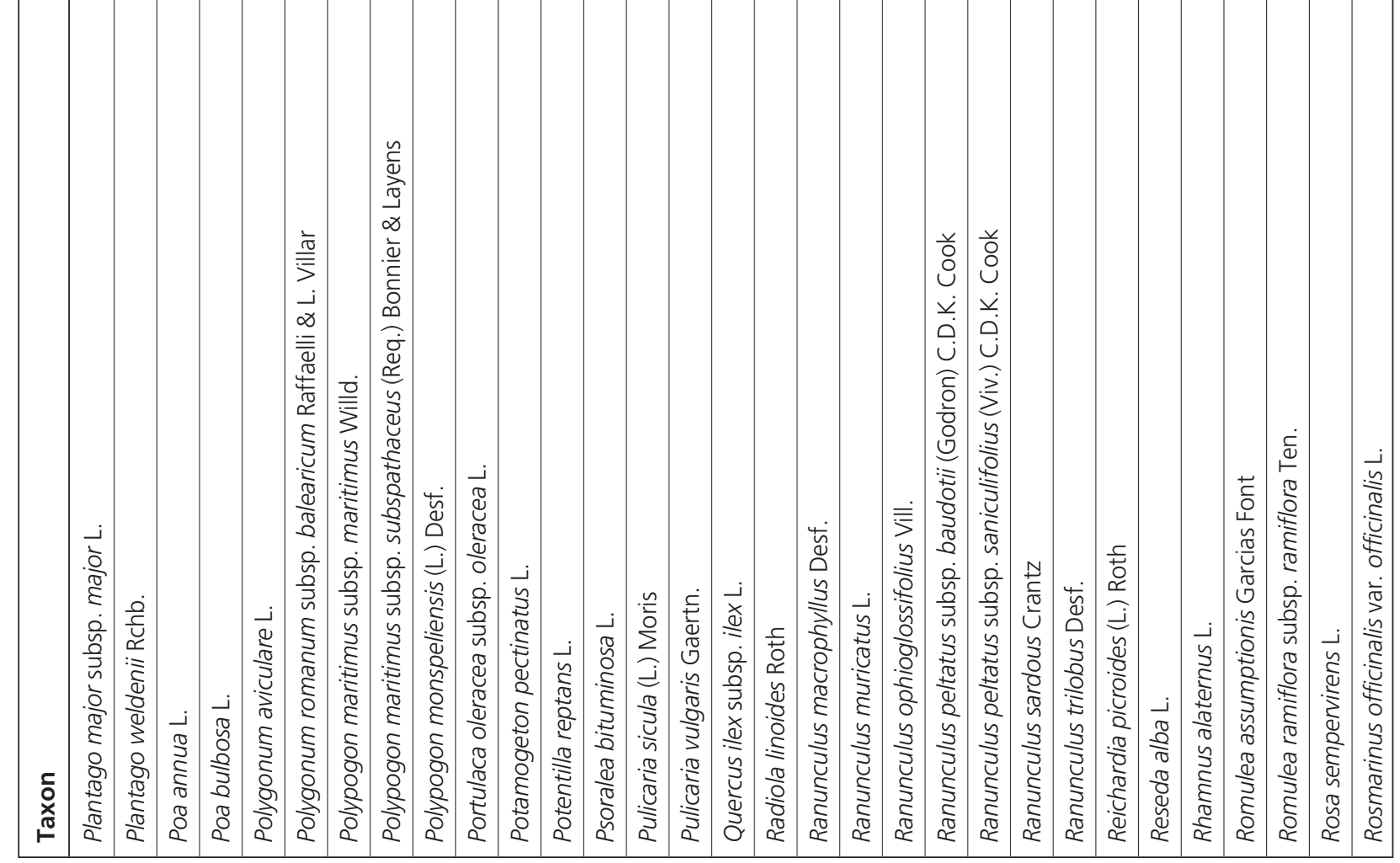




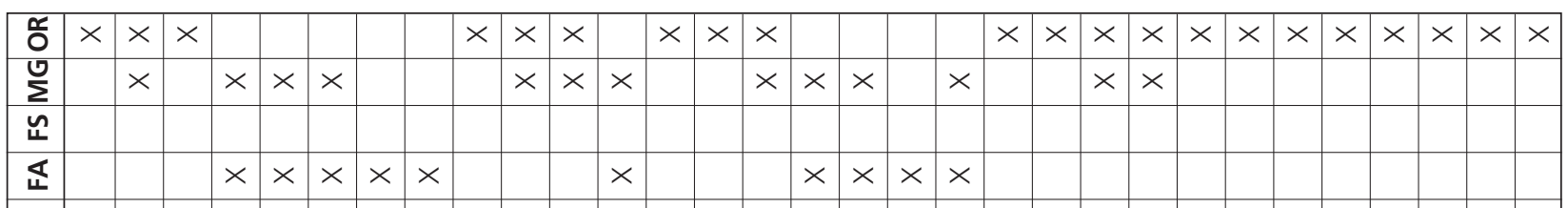

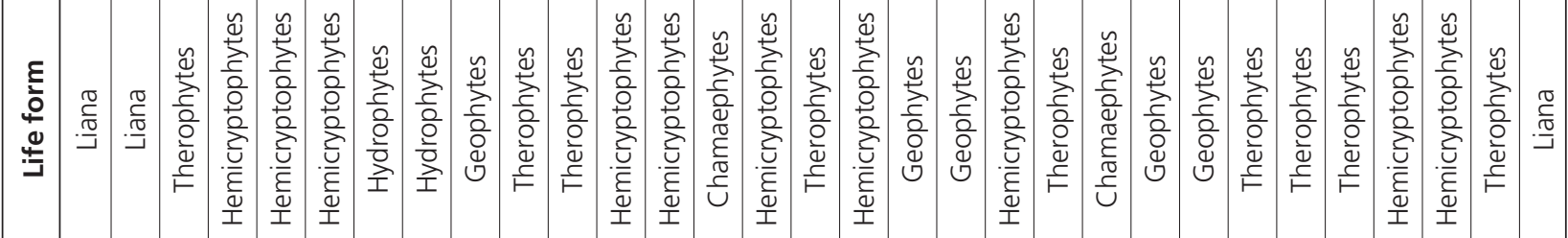

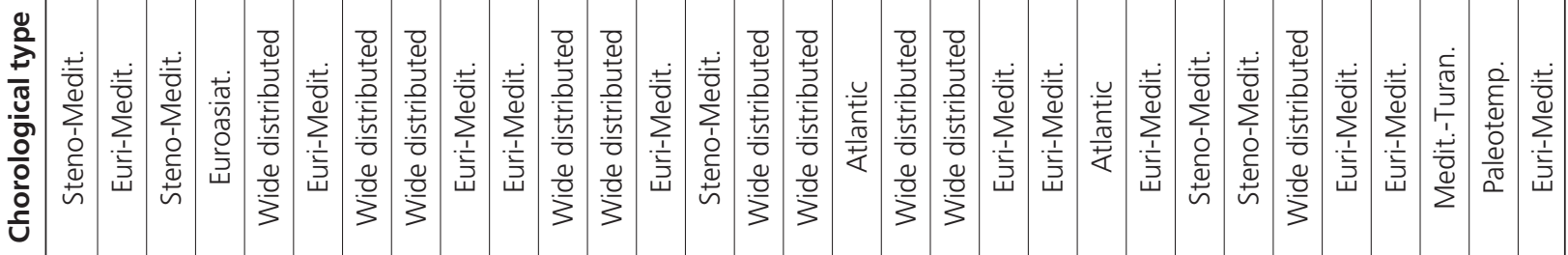

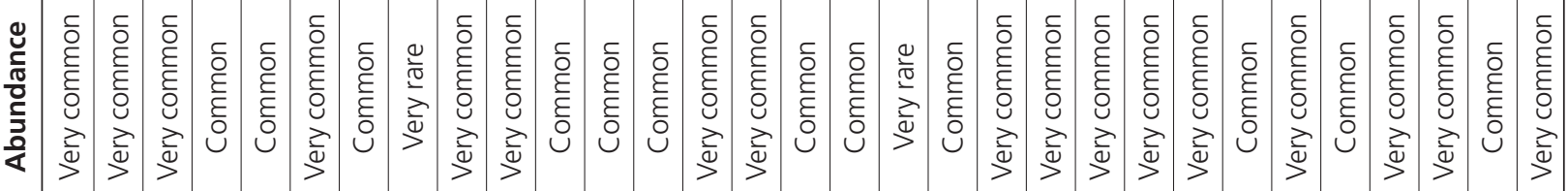

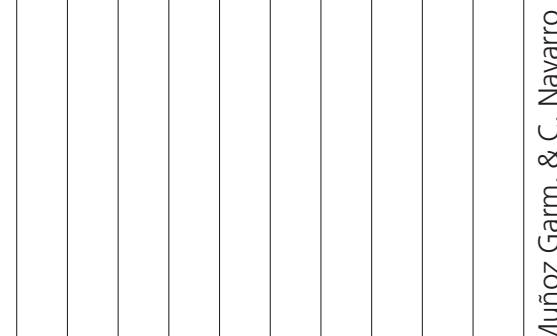

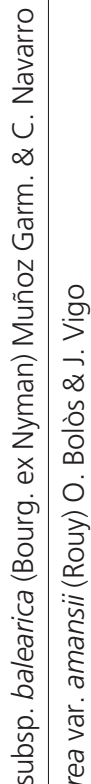

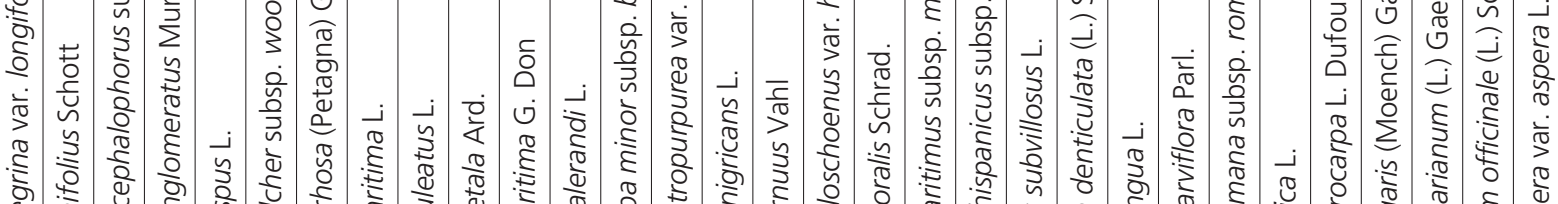

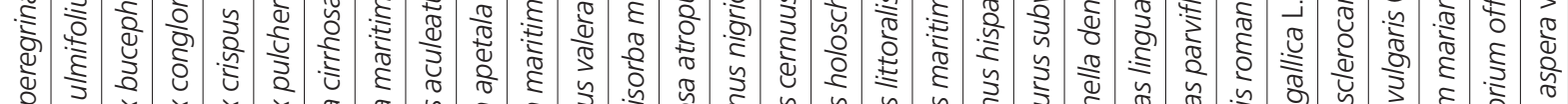

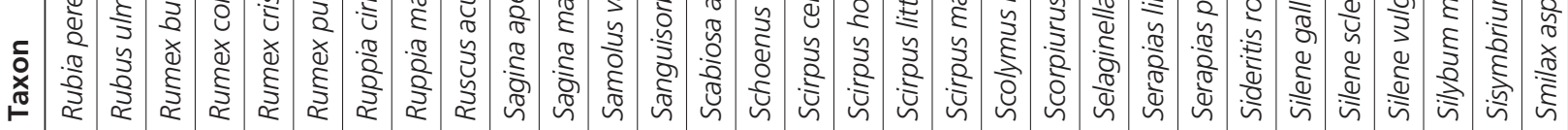




\begin{tabular}{|c|c|c|c|c|c|c|c|c|c|c|c|c|c|c|c|c|c|c|c|c|c|c|c|c|c|c|c|c|c|}
\hline \%ّ & $\times$ & & $\times$ & $\times$ & $\times$ & $\times$ & $\times$ & $\times$ & & & $\times$ & $\times$ & $\times$ & & & $\times$ & $\times$ & \begin{tabular}{l|l}
$\times$ & $\times$
\end{tabular} & $\times$ & $\times$ & $\times$ & $\times$ & & $\times$ & & $>$ & & $x$ & \\
\hline$\stackrel{W}{\Sigma}$ & $\times$ & $\times$ & $\times$ & $\times$ & $\times$ & $\times$ & $\times$ & & $\times$ & $\times$ & & & & $\times$ & $x$ & & $\times$ & $\times$ & & & & $\times>$ & $\times$ & $\times>$ & $\times>$ & $\times$ & $x$ & & $x$ \\
\hline$\tilde{u}$ & & & & $\times$ & & & & & & & & & & & & & & $x$ & & & & & & & & & & & \\
\hline $\mathbb{4}$ & & & & & & & & & & & & & & $\times$ & & & & & & & & & & & & & & & \\
\hline
\end{tabular}

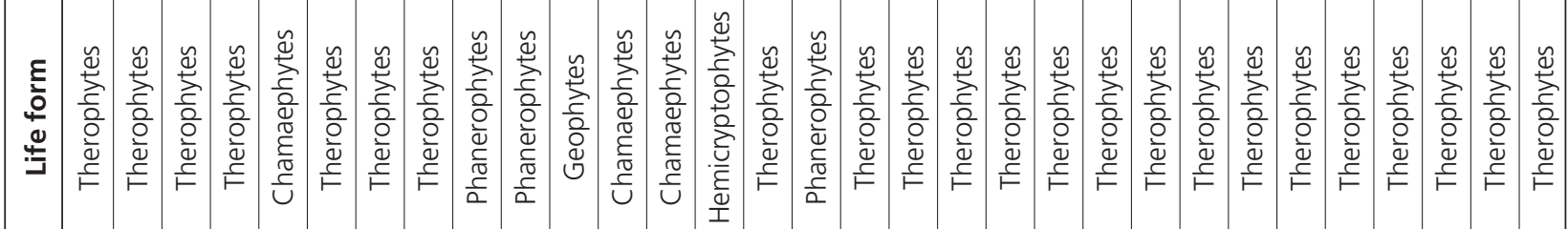

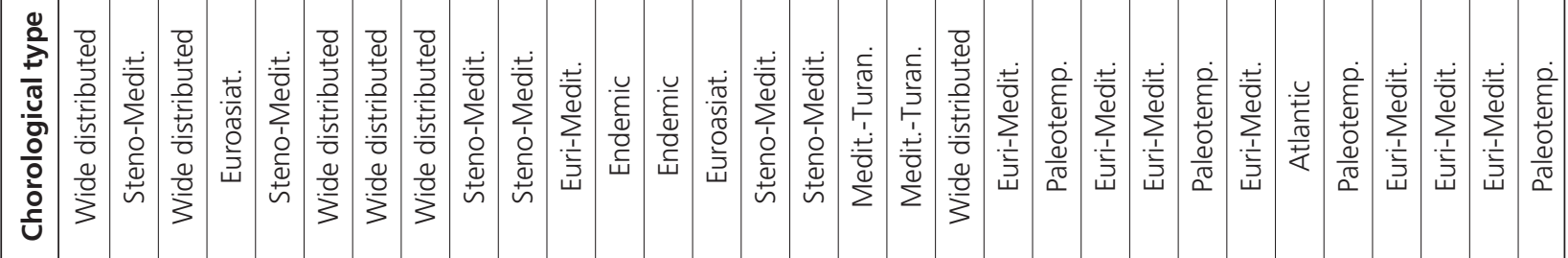

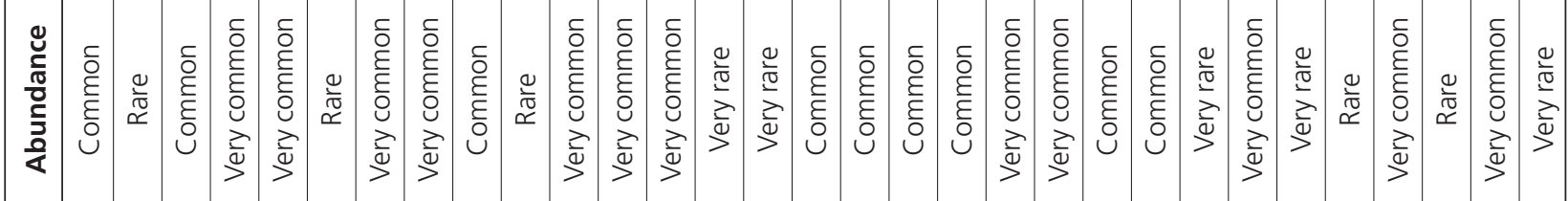

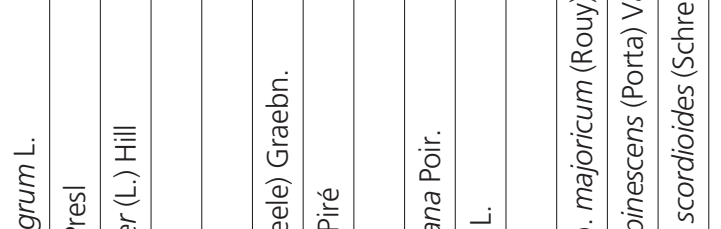

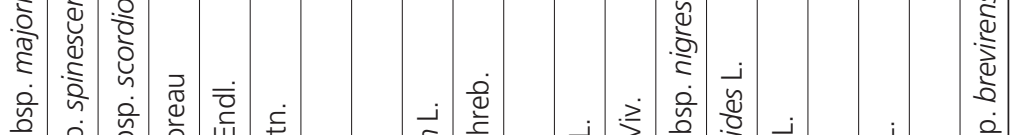

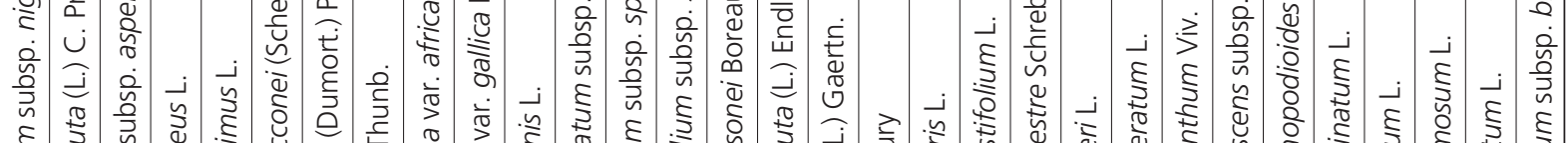

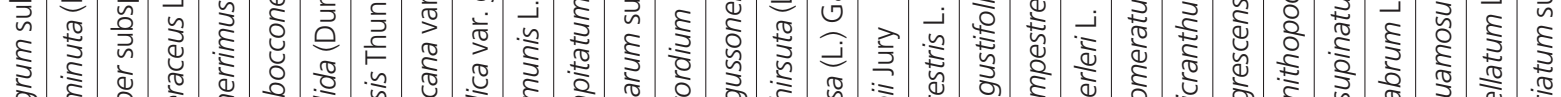

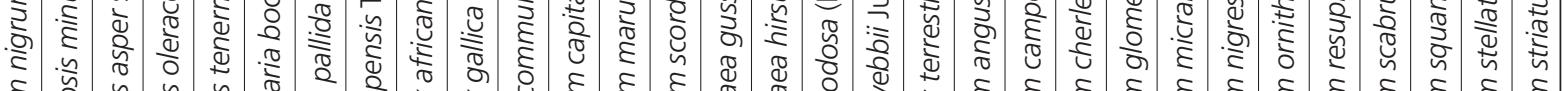

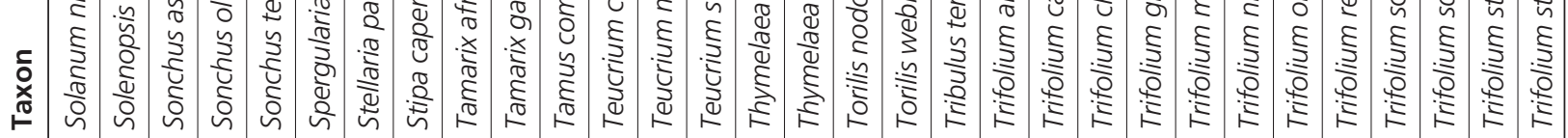




\begin{tabular}{|c|c|c|c|c|c|c|c|c|c|c|c|c|c|c|c|c|c|c|c|c|c|c|}
\hline 。ั & & & & & $\times$ & $\times$ & & $\times$ & $\times$ & $x$ & $\times$ & $\times$ & $\times$ & $\times$ & & & $\times$ & $\times$ & $\times$ & $\times$ & & \\
\hline$\stackrel{0}{\Sigma}$ & $\times$ & $\times$ & $\times$ & $\times$ & & $\times$ & & & & & & & & $\times$ & $\times$ & & & & & & & \\
\hline$\widetilde{్}$ & & & & & & & & & & & & & & & $\times$ & & & & & & & \\
\hline 昏 & & & & $\times$ & & & $x$ & & & & & & & & & $\times$ & & & & & $\times$ & $\times$ \\
\hline
\end{tabular}

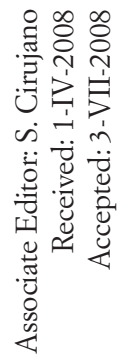

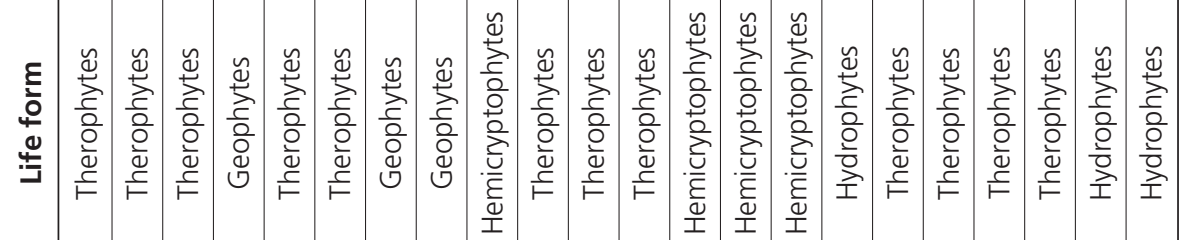

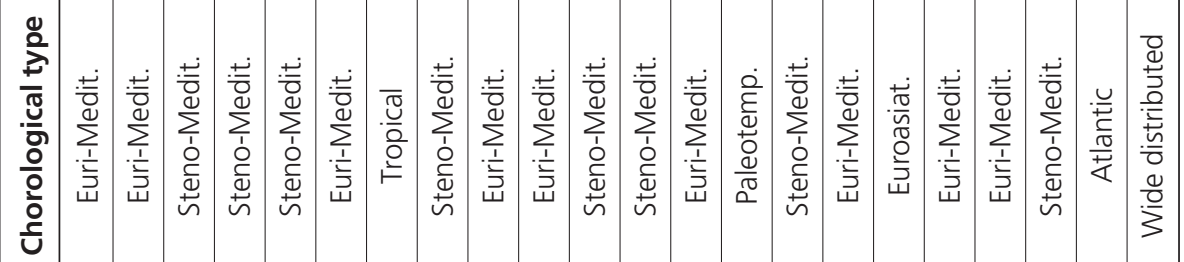

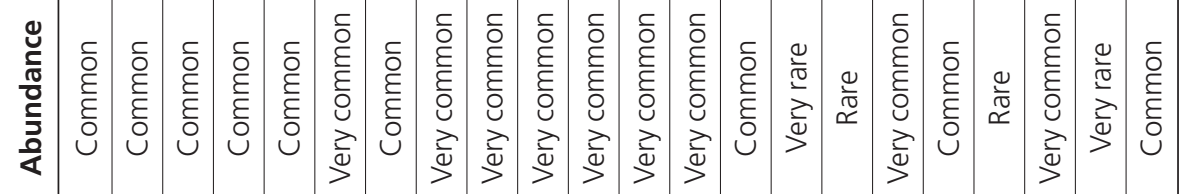

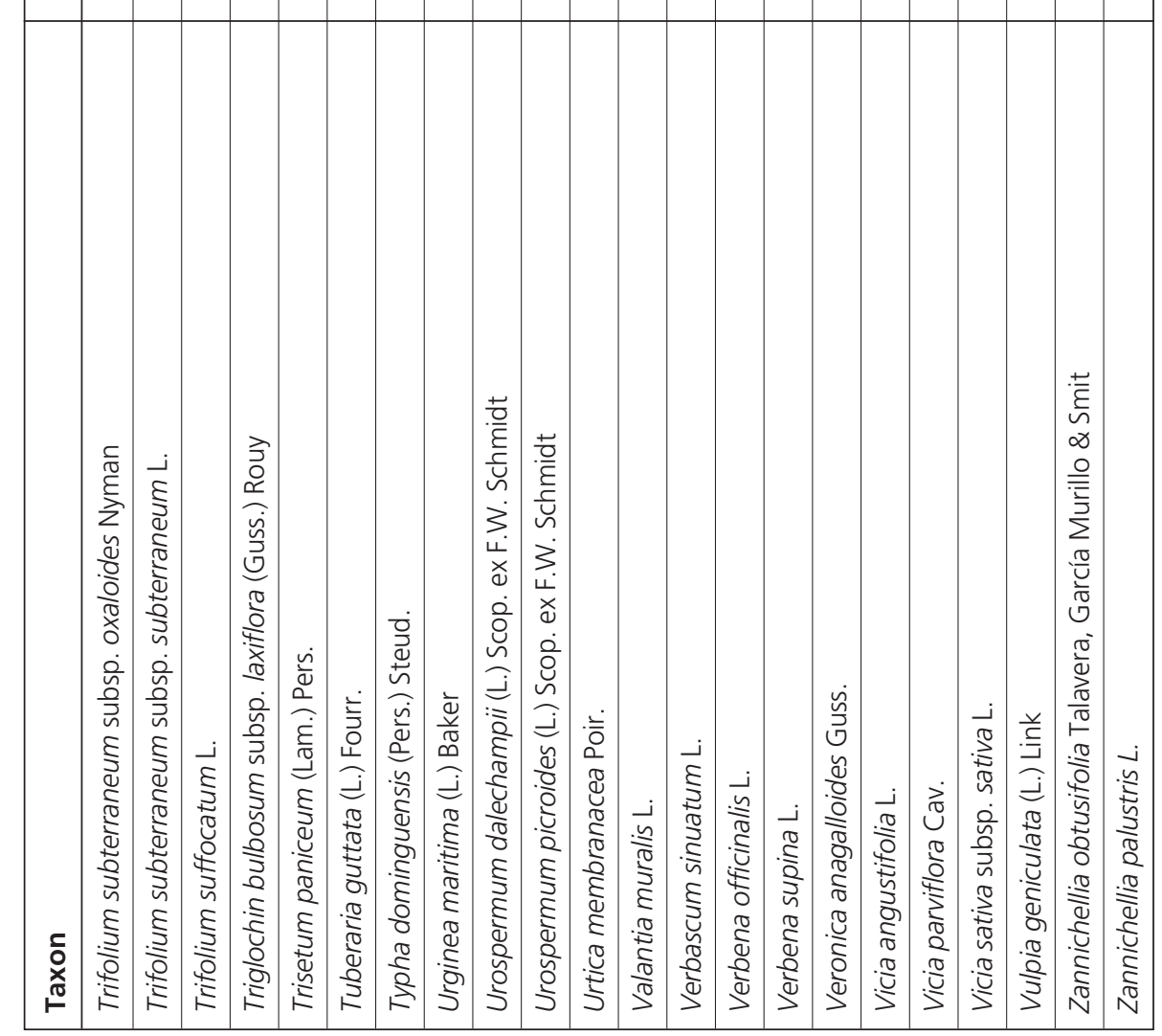

